Review

\title{
Aroma Volatiles in Tomato Fruits: The Role of Genetic, Preharvest and Postharvest Factors
}

\author{
Miriam Distefano ${ }^{1}$ (D), Rosario Paolo Mauro ${ }^{1, *(D)}$, David Page ${ }^{2}$ (D) Francesco Giuffrida $^{1}$ (D) Nadia Bertin $^{3}$ \\ and Cherubino Leonardi ${ }^{1}$ (D)
}

1 Dipartimento di Agricoltura, Alimentazione e Ambiente (Di3A), University of Catania, via Valdisavoia 5, 95123 Catania, Italy; miriam.distefano@unict.it (M.D.); francesco.giuffrida@unict.it (F.G.); cherubino.leonardi@unict.it (C.L.)

2 Institute Nationale de Recherche pour l'Agriculture, l'Alimentation et l'Environnement (INRAE), Avignon Université, UMR408 Sécurité et Qualité des Produits d'Origine Végétale, 84914 Avignon, France; david.page@inrae.fr

3 Institute Nationale de Recherche pour l'Agriculture, l'Alimentation et l'Environnement (INRAE), UR115 Plantes et Systèmes de Culture Horticoles, Site Agroparc, 84914 Avignon, France; nadia.bertin@inrae.fr

* Correspondence: rosario.mauro@unict.it; Tel.: +39-0954783314

Citation: Distefano, M.; Mauro, R.P.; Page, D.; Giuffrida, F.; Bertin, N.; Leonardi, C. Aroma Volatiles in Tomato Fruits: The Role of Genetic, Preharvest and Postharvest Factors Agronomy 2022, 12, 376

https://doi.org/10.3390/ agronomy12020376

Academic Editor: Andrea Liliana Clavijo McCormick

Received: 23 December 2021

Accepted: 31 January 2022

Published: 2 February 2022

Publisher's Note: MDPI stays neutral with regard to jurisdictional claims in published maps and institutional affiliations.

Copyright: (C) 2022 by the authors. Licensee MDPI, Basel, Switzerland. This article is an open access article distributed under the terms and conditions of the Creative Commons Attribution (CC BY) license (https:// creativecommons.org/licenses/by/ $4.0 /)$.

\begin{abstract}
Over the last few decades, the improvement of tomato aroma and flavour has gained growing attention among breeders, agronomists and food technologists, as it is reputed as a key tool to further consolidate tomato consumption in the global market. However, this represents a difficult task, since more than 400 volatile organic compounds (VOCs) differently contribute to tomato aroma and its flavour perception. The recent development of molecular tools has allowed us to identify some of the major alleles influencing the volatile composition of tomatoes. Nonetheless, such composition involves an intricate weave of polygenic systems, highly influenced by external, pre and postharvest factors. With few exceptions, our knowledge about the effects of these determinants is still scarce, making it difficult to draw sound conclusions to best manage the future genetic potential. The present review examines the existing knowledge on major VOCs influencing tomato organoleptic quality, including their classification, metabolic pathways, genetics, and technical features that affect their concentrations in fruits. Particular emphasis is placed on preharvest and postharvest factors influencing their quantitative and qualitative expression, whose integrated study with omic tools will be increasingly necessary for the perspective of disseminating reliable operational indications throughout the production/distribution chain.
\end{abstract}

Keywords: tomato; fruit quality; aroma volatiles; preharvest; postharvest

\section{Introduction}

The tomato (Solanum Lycopersicum L.) is the second most economically important vegetable crop in the world after the potato, being cultivated on a surface area of 5.0 Mha, and generating an export value of 14.1 billion dollars (considering both raw and processed products) [1]. The crop is mainly grown in Asia (2.6 Mha), followed by Africa (1.6 Mha), Europe (0.4 Mha), the Americas (0.4 Mha) and Oceania (0.01 Mha). The wide diffusion of the species flows from its adaptability to different growth conditions (both in open fields and greenhouses), as well as from the versatility of the product, which is exploitable for both fresh consumption and industrial processing [2-4]. Its climacteric, fleshy berries are a rich source of minerals (mainly $\mathrm{K}, \mathrm{P}$ and $\mathrm{Mg}$ ), vitamins (ascorbic acid and niacin), carotenoids (lycopene, $\beta$-carotene and lutein) and polyphenols (chlorogenic acid, quercetin, naringenin), making tomatoes an ideal component of modern diets [5,6]. Given its economic and nutritional importance, since the 1980s the interest in this crop has grown rapidly so that the tomato has become a model plant from a physiological and biotechnological viewpoint [7]. Over time, this has led breeders to permanently 
insert genes from wild Solanum species into domesticated tomatoes, with the perspective to improve crop yield, adaptability and disease resilience [8]. Many qualitative traits of tomato berries such as colour, shape, firmness, and shelf life have also been improved through the evolution of breeding techniques, with the aim to enhance product attractiveness and consumer satisfaction. Nonetheless, over the last few decades, consumers have started complaining about the poor flavour of modern tomatoes, so breeders, agronomists, and food technologists have begun to pay more attention to this trait [9]. The interest in this topic is evidenced by the rapid increase in the number of Scopus ${ }^{\circledR}$ papers dealing with VOCs over the last 30 years, especially from the early 2000s (Figure 1). However, designing tomato quality with improved flavour is a difficult task, as it involves multiple traits mainly related to fruit taste and aroma [10]. The taste of fruit is related to the concentrations of sugars (glucose, fructose and sucrose) and organic acids (mainly citric and malic), while its aromatic profile involves numerous volatile organic compounds (VOCs), whose interaction with taste and texture results in flavour perception (i.e., and integrated perception of taste and retronasal olfaction) $[11,12]$. These intrinsic properties represent an intricate weave involving many polygenic systems [13], generating a physiological complexity, which makes it difficult to respond to the emerging consumer demands. In the case of aroma, more than 400 volatile constituents have been identified in tomatoes, complicating the task of selective breeding even if a relatively limited number (less than $10 \%$ ) is actually reputed to have major organoleptic importance $[14,15]$. This polygenic nature implies that, beyond the genetic background, external factors such as environmental conditions, crop management, ripening stage, postharvest handling, storage, and processing can generate significant effects on tomato flavour [16,17]. Recently Tieman et al. [18] have identified major alleles influencing some key volatiles contributing to consumer appreciation, paving the way toward a new era in breeding for tomato quality traits. However, the understanding of the determinism linking the influence of environmental and technical factors on tomato volatiles is still in its infancy, making a volatile-based product quality design impossible.

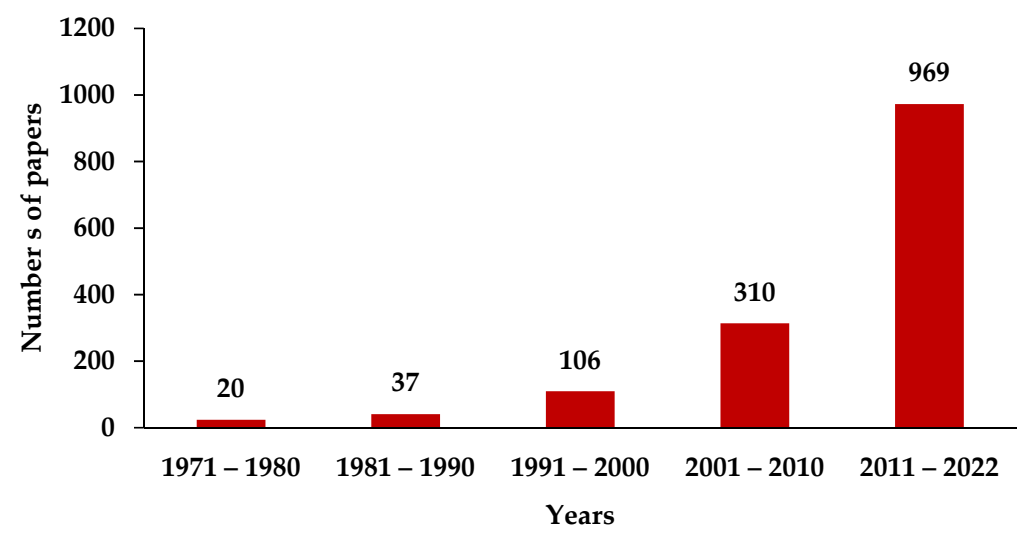

Figure 1. Number of journal papers accessed on Scopus ${ }^{\circledR}$ using the search terms 'Tomato' and 'Volatiles' for each decade of the past 51 years (accessed on 25 January 2022).

The aim of this paper is to examine the current knowledge about the pre and postharvest factors affecting the composition of aroma volatiles in tomatoes. An introduction to VOCs will be provided with reference to their chemical nature, biosynthetic pathways, and their rising role in determining tomato quality for fresh consumption. Then, the effects of cultivar, environment, crop management, postharvest handling, and processing conditions involved in the synthesis and postharvest evolution of VOCs will be exposed, with the aim of focusing on some technical perspectives for possible future research.

\section{Tomato Quality: Evolution and Emerging Aspects}

Since the second post-war period, the tomato has undergone an intense phase of breeding, leading to a strong cultivar specialization, so actually, a broad range of genotypes 
is available on the market, widely differing in fruit size, shape, pigmentation and average composition. The increase in yield, the improvement of fruit appearance, and shelf life have been key-breeding steps in enhancing crop profitability and product consumption on a global scale. Breeding activities oriented towards an adaptation to the processing industry have led to the development of specific varieties with a high level of dry matter content, which are adapted to field cropping and mechanical harvesting [19]. Moreover, breeding for tolerance/resistance to abiotic and biotic stressors had a pivotal role in improving the sustainability of the crop and the toxicological profile of the product. Nonetheless, such intense breeding activity is nowadays reputed to have contributed to consumers dissatisfaction toward the lack of flavour in modern tomato cultivars [20]. Improved traits such as higher yield potential and the concentration of fruit set over shorter periods have led to an increased fruit load, generating, in turn, a dilution effect of many chemicals responsible for flavour perception [21]. On the other hand, the improvement of tomato shelf life, the practice of harvesting at earlier ripening stages and postharvest refrigeration, alongside all the necessary processes that are used to bridge the spatial and temporal gap between production and consumption, nowadays are considered among the main culprits responsible for making tomato fruits less flavourful [22,23]. The improvement of fruit appearance has played a role in worsening the aromatic profile of tomatoes too. Improved cultivars for uniform fruit ripening, lacking the trait "green shoulder" (u-mutants fruits), which are deemed more appealing by consumers, have brought with them fewer chloroplasts and, consequently, a lower level of carotenoids and soluble solids, hence negatively contributing to the overall flavour [24]. From the industry's side of view, the quality aspect was mainly focused on the ability of fruits to produce textured purees, as the flavour was a less pregnant demand in a context where ingredients that corrected off- or low flavours, were used without consumer reproaches [19].

Improving flavour is currently one of the most important challenges for prompting further tomato consumption on a global scale, going far beyond a merely hedonistic task. Indeed, more flavoursome vegetables are expected to influence in the future the consumers' eating habits, shifting away from less healthy snack food alternatives and reducing additives in processed foods, so having positive reflexes on the incidence of chronic, non-communicable diseases and public health expenditure [9].

\section{VOCs in Tomatoes: Their Role, Classification and Biosynthetic Pathways}

\subsection{Contribution of VOCs to Tomato Flavour}

Volatile organic compounds are non-nutritional constituents produced by fruits, which spread up in the air and affect the overall aroma and flavour of tomatoes [25]. Decades of breeding and technical evolution of the crop have largely neglected these constituents, also because of objective difficulties in their quantification and in establishing their role in contributing to tomato eating quality [15]. Indeed, tomato volatiles are often present at picomolar or nanomolar concentrations, so complex gas chromatography-mass spectrometry (GC-MS) equipment and procedures are needed for their quantification [18,26]. Among the over 400 volatile compounds found in tomatoes, differences of many orders of magnitude exist between their abundances, with $\sim 30$ of them showing an appreciable concentration. Thus, the most abundant compounds, such as (Z)-3-hexenal or hexanal, can reach several $\mu \mathrm{g} \mathrm{g}^{-1}$ of fresh weight (FW) while others, such as $\beta$-damascenone or $\beta$-ionone, are present on the order of $\mathrm{ng} \mathrm{g}^{-1} \mathrm{FW}$ or less [27].

To overcome the difficulties in pyramiding the contribution of volatiles to tomato flavour, a widely accepted approach is based on the use of the odour thresholds and odour units [28]. The first variable refers, for a given compound, to the minimum concentration perceptible by the human nose, through its orthonasal olfaction [29]. The second variable derives from the ratio among the log of the concentration of a compound and its corresponding odour threshold [30]. Positive log odour units designate a significant contribution to tomatoes' aroma [26]. At least 16 tomato volatiles have positive odour units, including cis-3-hexenal, hexanal, 3-methylbutanal, trans-2-hexenal, trans-2- 
heptenal, 2-phenylacetaldehyde, $\beta$-ionone, 1-penten-3-one, $\beta$-damascenone, 6-methyl-5hepten-2-one, cis-3-hexenol, 2-phenylethanol, 3-methylbutanol, 1-nitro-2-phenylethane, 2-isobutylthiazole, and methyl salicylate [26]. Other volatiles with slightly negative odour units may contribute to the background aromatic notes [23]. However, this approach has some limits. First, it takes into account only the orthonasal perception (aroma) excluding the retronasal one, which is essential for flavour perception [12]. It has been observed that, for the same compound, different odour thresholds may correspond to these two specific perception channels [31]. Secondly, the odour threshold is estimated using a pure standard in water solution, instead of using tomato fruit samples [32]. To this end, it has been demonstrated that the volatiles' emission is highly influenced by the characteristics of the matrix in which they are dissolved [32]. Moreover, the perception of VOCs does not derive from an additive effect, but rather from multiple interactions among different compounds, all contributing to the overall flavour [31]. The existence of significant interactions has been demonstrated even between volatile and non-volatile compounds in the fruits, particularly sugars and organic acids, that can alter the perception of a volatile compound [11,33]. On the other hand, it has been demonstrated that there is a role of some aroma volatiles (e.g., the apocarotenoid volatiles) in enhancing the perception of tomato sweetness, regardless of the concentration of sugars, suggesting a different way for enhancing fruits' taste perception [34,35].

\subsection{Chemical Classification and Biosynthesis of VOCs}

Tomato volatiles are mainly included among aldehydes, ketones, alcohols, nitrogenand oxygen-containing compounds, esters, sulphur- and nitrogen-containing heterocyclic compounds and nitrogen compounds [26]. Due to this ample chemical heterogeneity, VOCs are commonly grouped also on the basis of their biochemical precursors (Table 1), as they mainly derive from the degradation of fatty acids, amino acids or carotenoids (Figure 2) [36]. 


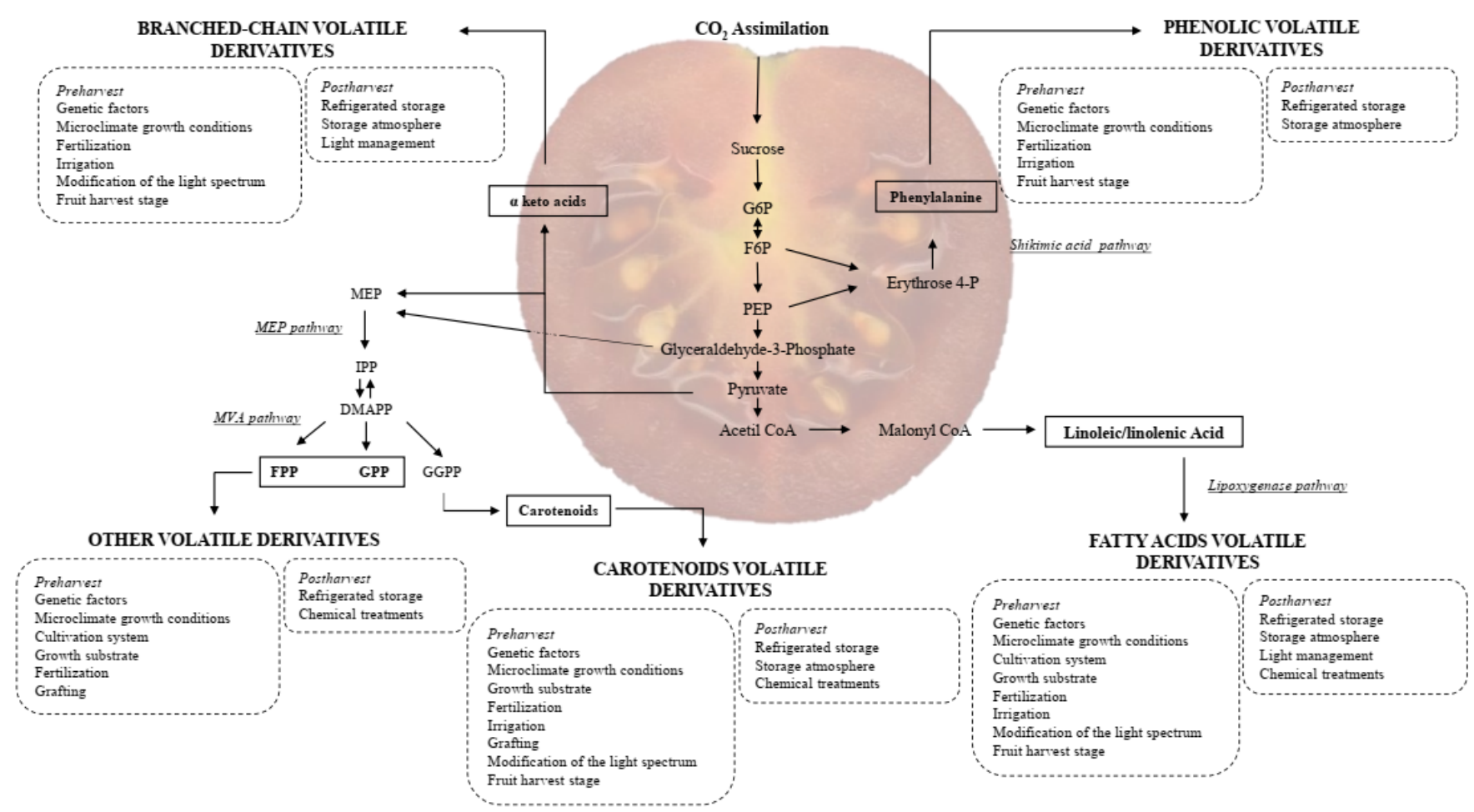

Figure 2. Metabolic pathways leading to the biosynthesis of main volatiles in tomatoes. Pathway names are grey and italicized, main class precursor compounds are in bold and boxed, and volatile classes are in bold and underlined. Abbreviations: Acetyl-CoA, acetyl coenzyme-A; DMAPP, dimethylallyl diphosphate; Erythrose 4-P, erythrose 4-phosphate; F6P, fructose 6-phosphate; FPP, farnesyl diphosphate; G6P, glucose 6-phosphate; GGPP, geranylgeranyl diphosphate; GPP, geranyl diphosphate; IPP, isopentenyl diphosphate; MEP, 2-C-methyl-D-erythritol 4-phosphate; MVA pathway, mevalonate pathway; PEP, phosphoenolpyruvate. 
Table 1. Main tomato volatiles along with their precursors, concentrations, odour thresholds in water, log odour units, and odour description (modified from Wang et al., 2016—Springer Nature).

\begin{tabular}{|c|c|c|c|c|c|}
\hline Volatile Compounds & Classification & $\begin{array}{c}\text { Average } \\
\text { Concentration }\left(\mathrm{ng}^{-1}\right)\end{array}$ & $\begin{array}{c}\text { Odour } \\
\left.\text { Threshold(ng } \mathrm{L}^{-1}\right)\end{array}$ & Log Odour Unit & Odor Descriptor \\
\hline \multicolumn{6}{|l|}{ Fatty acid derivatives } \\
\hline hexanol & Alcohol & 7 & 5000 & -1.9 & Resin, flower, green \\
\hline Z-3-hexenal & Aldehyde & 12 & 0.25 & 3.7 & Tomato, green \\
\hline E-2-heptenal & Aldehyde & 60 & 13 & 0.7 & Green \\
\hline 1-penten-3-ol & Alcohol & 110 & 400 & -0.6 & Sweet, fruity, grassy \\
\hline pentanol & Alcohol & 120 & 4000 & -1.5 & Balsamic \\
\hline$E$-2-pentenal & Aldehyde & 140 & 1500 & -1 & Strawberry, fruity, tomato \\
\hline Z-3-hexenol & Alcohol & 150 & 70 & 0.3 & Green \\
\hline E-2-hexenal & Aldehyde & 270 & 17 & 1.2 & Green \\
\hline 1-penten-3-one & Ketone & 520 & 1 & 2.7 & Fruity, floral, green \\
\hline hexanal & Aldehyde & 3100 & 4.5 & 2.8 & Green, grassy \\
\hline \multicolumn{6}{|l|}{ Carotenoid derivatives } \\
\hline epoxy- $\beta$-ionone & Ketone & 1 & 100 & -2 & Fruity, sweet, wood \\
\hline pseudoionone & Ketone & 1 & 800 & -1.9 & Balsamic \\
\hline$\beta$-damascenone & Ketone & 1 & 0.002 & 2.7 & Fruity \\
\hline neral & Aldehyde & 2 & 30 & -1.2 & Lemon \\
\hline$\beta$-cyclocitral & Aldehyde & 3 & 5 & -0.2 & Mint \\
\hline$\beta$-ionone & Ketone & 4 & 0.007 & 2.8 & Fruity, floral \\
\hline geranial & Aldehyde & 12 & 32 & -0.4 & Citrus \\
\hline geranylacetone & Ketone & 57 & 60 & -0.02 & Sweet, floral, estery \\
\hline 6-methyl-5-hepten-2-one & Ketone & 130 & 50 & 0.4 & Fruity, floral \\
\hline \multicolumn{6}{|l|}{ Amino acid derivatives } \\
\hline 3-methylbutanenitrile & N-compound & 13 & 1000 & -1.9 & Pungent \\
\hline 2-phenylacetaldehyde & Aldehyde & 15 & 4 & 0.6 & Floral, alcohol \\
\hline 1-nitro-2-phenylethane & $\mathrm{N}$-compound & 17 & 2 & 0.9 & Musty, earthy \\
\hline 3-methylbutanal & Aldehyde & 27 & 0.2 & 2.1 & Musty \\
\hline 2-isobutylthiazole & $\begin{array}{c}\text { S- and } \\
\text { N-compound }\end{array}$ & 36 & 3.5 & 1 & Tomato vine, green \\
\hline methyl salicylate & Ester & 48 & 40 & 0.008 & Wintergreen \\
\hline 3-methylbutanol & Alcohol & 380 & 250 & 0.2 & Earthy, musty \\
\hline 2-phenylethanol & Alcohol & 1900 & 1000 & 0.3 & Nutty, fruity \\
\hline \multicolumn{6}{|l|}{ Others } \\
\hline linalool & Alcohol & 2 & 6 & -0.5 & Citrus, fruity, sweet \\
\hline 1-nitro-3-methylbutane & $\begin{array}{c}\mathrm{N} \text { - and } \\
\text { O-compound }\end{array}$ & 59 & 150 & -0.4 & 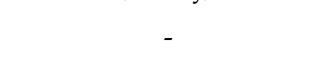 \\
\hline
\end{tabular}

\subsubsection{Fatty Acids Derivatives}

The biosynthesis of fatty-acid-derived volatiles takes place once the separation between these substrates and some enzymes are lost due to the disruption of cellular tissues and during ripening [37].

The C18 linoleic (18:2) and linolenic (18:3) acid, both derived from the acylglycerides, through lipid degradation by the lipoxygenase (TomLoxC) and 13-hydroperoxide lyase (13-HPL) enzymes produce the corresponding short-chain C6 aldehydes such as hexanal, cis-3-hexenal, 1-hexanol and the C5 volatile 1-penten-3-one [31,37]. Specifically, cis-3hexenal might be isomerized to trans-2-hexenal either by enzymatic or non-enzymatic reactions. The aldehydes, such as hexanal and cis-3-hexenal, can be reduced into the corresponding alcohols by the enzyme alcohol dehydrogenase (ADH2). Then, the alcohols can be metabolized into esters by the alcohol acetyl transferases (AAT) in wild tomato species, such as Solanum pennellii Correll, but are normally absent in cultivated tomatoes [38]. The C6 volatiles are the most abundant in tomato fruits and are associated with odour notes of tomato-like, grassy, and green [39]. Other volatiles derived from fatty acids, such as 1-penten-3-one, 1-penten-3-ol, trans-2-pentenal, pentanal, and pentanol are synthesized through the involvement of the isoform of tomato lipoxygenase in their biosynthetic pathway [40]. These compounds give fruity notes and seem to be particularly appreciated by consumers [40]. 


\subsubsection{Amino Acid Derivatives}

Among the volatiles involved in tomato flavour, many derive from amino acids and can be classified into two groups: phenolic and branched-chain volatiles [31]. The synthesis of phenolic volatiles starts with the shikimic acid pathway, leading to the formation of their precursor phenylalanine. By means of aromatic amino acid decarboxylases (AADCs) phenylalanine is decarboxylated in phenylethylamine, which is then converted to 2-phenylacetonitrile, 1-nitro-2-phenylethane, or 2-phenylacetaldehyde through a series of reactions that are still not fully characterized [26]. Subsequently, the 2-phenylacetaldehyde is reduced to its respective alcohol, 2-phenylethanol. This reaction is performed by enzymes belonging to the family of phenylacetaldehyde reductases (PARs), LePAR1 and LePAR2, whose synthesis, such as via the AADC enzymes, is not constant during the maturation process [41]. 2-Phenylethanol and 2-phenylacetaldehyde are important phenolic volatiles, conferring nutty and fruity notes to tomato fruits, while 1-nitro-2-phenethane is perceived to have an earthy aroma [26].

Branched-chain amino acid derivatives are other important volatiles, but their exact biosynthetic pathway is still not well known. Nowadays it is supposed that their synthesis could begin from either an $\alpha$-ketoacid or an amino acid [9]. Valine, leucine, and isoleucine are initially transaminated into their branched-chain $\alpha$-ketoacids by the action of the branched-chain amino acids; the aminotransferases (BCATs), which are a family of enzymes located in the chloroplasts, mitochondria and cytoplasm [42]. Although six different BCATs have been identified in tomatoes, SIBCAT1 and SIBCAT2 are reported to participate in the biosynthesis of branched-chain amino acid derivatives [43]. A series of volatiles is thus produced, such as 3-methylbutanal/ol, 2-methylbutanal/ol and 2-isobutylthiazole $[9,31,44]$. These compounds release earthy, tomato vine, green and musty notes [26].

\subsubsection{Carotenoid Derivatives}

Another key class of tomato volatiles derive from the degradation of long-chain molecules such as carotenoids or norisoprenes, which can be considered to be irregular terpenoids [31,45]. As a result of the degradation of carotenoids, their content is strongly correlated with the progression of tomato fruits' ripening, mainly due to the accumulation of lycopene, even if their production is not linear and their overall concentration remains low [31]. Although they are present in very low concentrations, they have a primary role in conferring floral/fruity notes to tomatoes and increasing product appreciation [10,46,47].

In ripe tomatoes, the cytosolic enzymes LeCCD1A and LeCCD1B perform an oxidative cleavage of multiple linear carotenoids, either at the 5,6,7,8, or 9,10 positions, and cyclic carotenoids at the 9,10 position. This leads to the biosynthesis of dialdehydes and ketones, forming several $\mathrm{C} 13$ volatiles such as pseudoionone, $\beta$-ionone, 6 -methyl-5-hepten-2-one, $\beta$-damascenone and geranylacetone, which is reported to be generated by the oxidative cleavage of phytoene, phytofluene, $\zeta$-carotene, and neurosporene $[18,26,47-49]$. In tomatoes, the LeCCD1 cleavage of lycopene at the 5,6 position leads to 6-methyl-5-hepten-2-one, which is associated with the tomato-like flavour and sweet floral aroma of tomatoes [48,50]. Though LeCCD1A and LeCCD1B represent the main systems of apocarotenoid volatile biosynthesis, it has been reported that the carotenoid cleavage dioxygenases CCD4 and CCD7, localized in plastids, have the capacity to generate volatiles from $\beta$-carotene, lutein and violaxanthin [51,52].

Other significant apocarotenoid volatiles, generated by LeCCD1A and LeCCD1B, seem to be two aldehyde isomers, geranial and neral ((Z)- and (E)- citral) that have notes of citrus and lemon, contributing as background aromas and even having negative odour unit values $[33,53]$. Several variables including precursors and their levels, enzymatic or non-enzymatic processes like photo-oxidation, and growing conditions influence the synthesis of carotenoid-derived volatiles [54-56] 


\subsubsection{Others}

There are several chemical families and different biosynthetic pathways, many of which have not been identified, that participate in the biosynthesis of tomato volatiles. Among these, a group of compounds seems to follow the phenylpropanoid biosynthetic pathway and have (E)-cinnamic acid as a common precursor [31]. An as-of-yet cryptic biosynthetic pathway leads to the synthesis of eugenol, catechol and guaiacol, which are thought to confer clove-like and smoky aromas [57,58]. In addition, methyl salicylate, produced by the methylation of salicylic acid, is one of the few volatiles derived from esters that is relevant for tomato aroma, following the phenylpropanoids catabolism. Its higher presence has been found in unripe tomato fruits and, according to its anti-herbivore defence in plant tissues [23,59], seems to be unwelcomed by consumers [54,60].

Terpenoids generate a heterogeneous set of volatiles, specifically sesquiterpenoids (C15) and monoterpenoids (C10). These compounds are present within the green tissues of tomato plants but poorly present in ripe fruits, where their contribution to aroma seems secondary [31]. They derive from isopentenyl diphosphate (IPP) and its isomer dimethylallyl diphosphate (DMAPP) and can be synthetized following two alternative pathways. The first precursor pathway is localized in the cytosol, where the mevalonic acid pathway uses acetyl-CoA to produce IPP. The second precursor pathway takes place in plastids, where the methylerythritol phosphate pathway produces DMAPP and IPP from pyruvate and glyceraldehyde-3-phosphate. From these two molecules, all the monoterpenoids and sesquiterpenoids are originated through successive synthetic steps [55]. The main mono and sesquiterpenoids involved in tomato aromas are limonene, linalool, $\alpha$-terpineol, which have notes of citrus and lemon [26]. Alternatively, tomato volatiles can be produced by the hydrolysis of glycosides. During ripening, volatiles such as phenylacetaldehyde or 3-methylbutanal could be produced by the hydrolysis of glycosides, which are previously oxidized from their corresponding alcohols by enzymatic processes [61].

Another potentially important volatile is 4-hydroxy-2,5-dimethyl-3 (2H) -furanone (HDMF), which may be derived from fructose-1,6-diphosphate [62]. Although its biosynthetic pathway is still not exactly known and is present at low concentrations, this compound seems to be promising for improving tomato aromas [9,10]. HDMF is also produced during thermal processing as a by-product of the Maillard reaction. Other compounds like 2-acetylfuran or 2-pentylfuran result from the same reactions, explaining why they are either not present, or are present as traces in fresh tomatoes [63]. Dimethyl sulphide, one of the major VOCs in tomato products, comes also from the heat-driven conversion of the free amino acid S-methionine [64].

\section{Genetic Factors Affecting Tomato Volatiles}

The genetic background of the cultivated germplasm represents one of the most important determinants for the overall quality of tomatoes $[39,65]$. Since the end of the 19 th century, new tomato cultivars have been obtained by growers in different growing conditions through selection within the available germplasm [66]. The resulting genetic bottleneck was accentuated in the 20th century with the diffusion of the $\mathrm{F}_{1}$ hybrids [66]. Accordingly, it has been estimated that the genomes of modern tomatoes contain less than $5 \%$ of the genetic variation that existed among their wild relatives, as demonstrated through DNA technologies [8]. The dramatic allelic depletion was reflected, also, in the poor concentrations of some secondary metabolites that are present in the fruits of modern cultivars, originating from intensive breeding for commercial traits such as fruit shape, colour, size and shelf-life [5]. In particular, breeding for shelf life, which started in the 1980s, has led to the introduction of some genes that alter the ripening process, such as rin (ripening inhibitor), nor (non-ripening) and $\mathrm{nr}$ (never ripe) [66]. It has been shown that these genes inhibit or dramatically slow down fruit ripening by acting on the synthesis of ethylene (the main plant hormone involved in fruit ripening), hence negatively affecting their volatile composition [10]. Indeed, a reduced level of volatiles in ethylene-deficient tomato mutants as well as in transgenic fruits with delayed/inhibited ripening via the 
suppression of ethylene synthesis has been reported [67-69]. This is also the case for the down-regulation of cell wall-digesting enzymes, such as polygalacturonase (PG) and pectin methylesterase (PME), that influence the activity of 1-aminocyclopropane-1-carboxylic acid (ACC) oxidase, the enzyme that converts ACC into ethylene [70].

Despite the actual importance of volatiles in tomato quality, only recently has there been a growth of evidence regarding the genomic regions encoding their synthesis (Table 2). Over recent years several experiments have been performed in order to elucidate the genetic control of volatile expression in tomato fruits [71,72]. Saliba-Colombani et al. [73] crossed the large-fruited tomato 'Levovil' with the cherry-type 'Cervil', detecting 26 QTLs for aroma volatiles, which were mainly localized on chromosomes 2, 3, 4, 8, 9, 11 and 12. The detected QTLs were mainly involved in the expression of 3-methylpentan1-ol, 3-(methylthio) propane, eugenol and orthomethoxyphenol. In a study involving an S. pennellii introgression line and the S. Lycopersicum inbred line M82, Tieman et al. [74] identified 25 loci linked to 23 different volatiles, including some deriving from amino acids, lipids, and carotenoids, and pointed out that the synthesis of carotenoid-derived volatiles was directly dependant on fruit carotenoid content, as is the same for $\beta$-ionone and pseudoionone. A further study using 89 interspecific populations deriving from S. Lycopersicum cv. E6203 (LA4024) and S. habrochaites accession LA1777, led to the identification of 30 loci related to one or more flavour volatiles' expression [75]. The authors identified new QTLs encoding for the synthesis of geranylacetone and 6-methyl-5-hepten-2-one on chromosome 2, and 3-methylbutanol and 3-methylbutanal on chromosome 4. More recently, Tieman et al. [18] have studied the genetic differences in the flavour profile of 398 tomato genotypes, including modern varieties, heirlooms and wild ecotypes (S. pimpinellifolium and S. Lycopersicum var. cerasiforme), detecting genomic loci contributing to the expression of several flavour compounds, including sugars, organic acids and volatiles. Through panel tests, a genome-wide association study, and a targeted metabolome quantification, the authors have shown that 13 volatiles actively contributing to flavour profile were higher in the heirloom varieties, and identified loci associated with significant effects for 23 volatiles. Moreover, they described candidate genes and allele combinations contributing to the fruit's concentration of guaiacol, methyl salicylate, and some carotenoid-derived volatiles such as geranylacetone and 6-methyl-5-hepten-2-one.

The variation of fatty-acid-derived volatiles among tomato genotypes is very high, whereas the knowledge about their synthesis and regulation is still limited [15]. Garbowicz et al. [76] using a S. pennellii introgression line (IL), performed a QTL analysis allowing the identification of three candidate genes involved in the synthesis of specific volatiles through the cleavage of fatty acids, i.e., a presumed lecithin-cholesterol acyltransferase and two members of the class III lipase gene family, LIP1 and LIP2. 
Table 2. Loci associated with some aroma volatiles in tomatoes (modified from Klee and Tieman, 2013-Cell Press).

\begin{tabular}{|c|c|c|c|c|c|}
\hline Locus & Associated Volatile/s & C number & Precursors & Identification & Reference \\
\hline $\mathrm{ADH}$ & $\begin{array}{l}\text { Hexanal:hexanol ratio } \\
\text { Phenylacetaldehyde, }\end{array}$ & C6 & Fatty acids & $\mathrm{BP} / \mathrm{QTL}$ & Speirs et al., 1998 \\
\hline AADC & $\begin{array}{l}\text { 2-phenylethanol,1-nitro- } \\
\text { 2-phenethane, } \\
\text { 2-phenylacetonitrile }\end{array}$ & $\mathrm{C} 8$ & Phenylalanine & BP/QTL & Tieman et al., 2006 \\
\hline PAR & $\begin{array}{l}\text { 2-Phenylethanol } \\
\text { Z-3-Hexenal, }\end{array}$ & $\mathrm{C} 8$ & Phenylalanine & $\mathrm{BP}$ & Tieman et al., 2007 \\
\hline LoxC & $\begin{array}{l}\text { Z-3-hexenol, hexanal, } \\
\text { hexanol }\end{array}$ & C6 & Fatty acids & CG & Chen et al., 2004 \\
\hline SAMT & Methylsalicylate & $\mathrm{C} 8$ & Esters & $\mathrm{BP}$ & Tieman et al., 2010 \\
\hline СТOMT & $\begin{array}{l}\text { 2-Methoxyphenol } \\
\text { (Guaiacol) }\end{array}$ & $\mathrm{C} 7$ & Phenols & $\mathrm{BP}$ & Mageroy et al., 2012 \\
\hline CXE1 & Multiple alcohols & $\mathrm{Cn}$ & $\begin{array}{l}\text { Fatty acids, } \\
\text { amino acids }\end{array}$ & QTL & Goulet et al., 2012 \\
\hline CCD1 & Multiple apocarotenoids & $\mathrm{Cn}$ & Carotenoids & CG & Simkin et al., 2004 \\
\hline GT1 & $\begin{array}{c}\text { Multiple } \\
\text { phenylpropanoids }\end{array}$ & $\mathrm{Cn}$ & Amino acids & QTL & Tikunov et al., 2013 \\
\hline LIP1, LIP2 & Z-4-Decenal & C10 & Fatty acids & QTL & Garbowicz et al., 2018 \\
\hline
\end{tabular}

AADC: aromatic amino acid decarboxylase; PAR: phenylacetaldehyde reductase; LoxC: 13-lipoxygenase SAMT: salicylic acid methyltransferase; CTOMT: catechol-O-methyltransferase; CXE1: carboxylesterase; CCD1: carotenoid cleavage dioxygenase; LIP1 and LIP2: lipases. BP: biochemical pathway; CG: candidate gene; QTL: quantitative trait locus (Klee and Tieman, 2013, modified).

\section{Preharvest Factors Affecting Tomato Volatiles}

\subsection{Grafting}

Grafting is a popular, asexual propagation technique for both solanaceous plants and cucurbits, consisting of the union of two plant genotypes, independently selected for root (rootstock) and shoot (scion) characteristics. The technique is primarily used to maximize yields and overcome unfavourable environmental growth conditions [77-79]. From a qualitative viewpoint, there are few (and no univocal) results about the effects of this technique on tomato volatiles because of the complex interactions between rootstock and scion and their largely unknown biosynthetic pathways (Table 3). Bartoshuk et al. [80] found a significant effect of grafting on the organoleptic traits of the tomato heirlooms 'Cuore di Bue' and 'Brandywine' grafted onto the hybrids 'Multifort' and 'Survivor'. The results of consumer tests on fully ripe tomatoes, though variable from year to year, revealed some negative impacts of grafting on fruits' sensorial traits such as appearance, overall acceptability and flavour. Krumbein and Schwarz [81] studied the effects of grafting on the flavour compounds of 'Piccolinos' (cocktail tomato) and 'Classys' (round truss tomato), either self-grafted or grafted onto 'Brigeors' and 'Maxiforts'. Overall, the heterografts increased the content of three lignin-related volatiles, namely, methyl salicylate, guaiacol and eugenol. Grafting 'Classys' onto 'Brigeors' decreased carotenoids by $8 \%$, resulting in decreases of three carotenoid-derived volatiles, i.e., geranylacetone, $\beta$-cyclocitral and $\beta$-ionone. The authors attributed this reduction to a decrease in carotenoid concentrations in the fruits, driven by the graft-induced dilution effects of tomatoes, strengthening the evidence of a direct link between carotenoid content and the volatile compounds that are derived from them, as previously reported [82].

\subsection{Growth Environment and Conditions}

Seasonal and environmental variations in microclimate conditions are of paramount importance in defining the quality and volatile profile of tomatoes [15,83-85]. Several authors have reported the central role of the growth environment in modulating the VOC expression of horticultural crops. In an experiment carried out by Cebolla-Cornejo et al. [86], the effects of the growth environment (screenhouse vs. open field) was evaluated on the 
volatile composition of four Spanish traditional tomato varieties (CDP8908, CDP0916, CDP8075, and CDP9944) and two hybrids ('Bond' and 'Cambria'). Among the 25 volatiles examined, the growth environment significantly influenced hexane and methyl salicylate. Specifically, hexane showed higher log odour units in the fruits obtained in the open field, whereas the opposite was recorded for methyl salicylate. Moreover, the authors reported a reduced level of sugars and a similar level of organic acids in screenhouse tomato fruits, a feature contributing to their lower organoleptic quality.

Table 3. Significant variations of main volatile compounds ascertained in tomatoes in relation to pre-harvest factors.

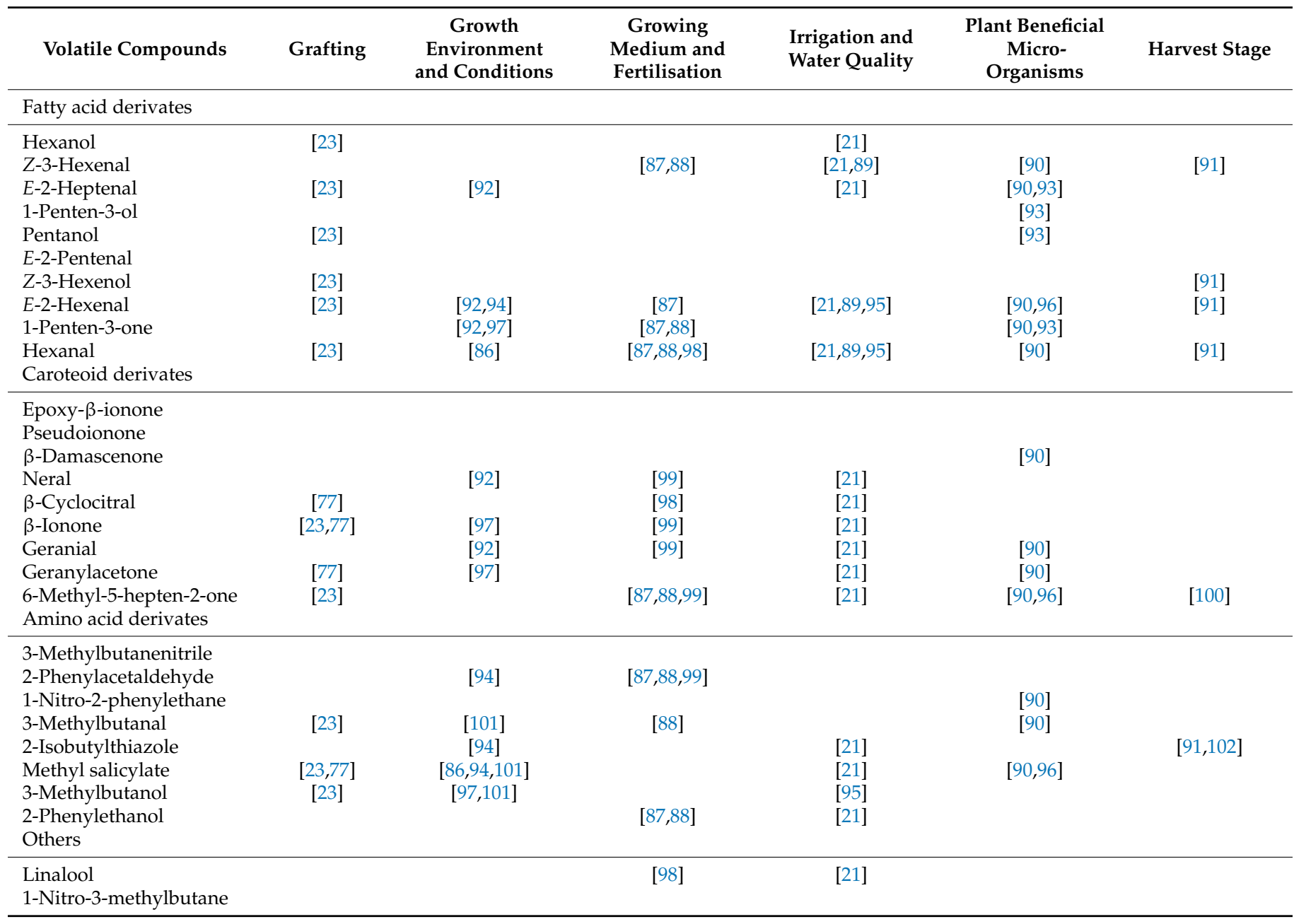

Absence of references indicates lack of reports in literature.

In off-season greenhouse cultivations, Baldwin et al. [97] evaluated the temporal variation of 29 aroma volatiles over multiple months (March, June, and December) along 6 cultivation years, using 29 tomato genotypes (breeding lines, experimental and commercial hybrids) differing in their overall flavour characteristics. They found that the highest sweetness, flavour chemical concentration, and perception were associated with fruits harvested in June, followed by those harvested in March and then in December (the poorest ones), with a key contribution to improving the perception of sweetness being played by acetaldehyde, 2 + 3-methylbutanol, geranylacetone, 1-penten-3-one 6-methyl-5-hepten-2one and $\beta$-ionone. The authors argued that, beyond the variability recorded across years, the increased day length, solar radiation, and temperature experienced during spring had a primary role in modulating the volatile fingerprint and improving the overall quality traits of the studied germplasm. Similarly, Liu et al. [94] by integrating the use of sensory 
evaluation and analytical determinations, investigated the influence of planting in March (in-season tomatoes) and July (off-season ones) on the composition of the 'Hezuo 903' greenhouse tomato volatiles. The authors reported an overall higher acceptability of the in-season tomatoes, together with the presence of some key volatiles, specifically characterizing the in-season (phenylacetaldehyde) and off-season fruits (e.g., E-2-hexenal and methyl salicylate). They hypothesized that the increase of volatiles such as 2-isobutylthiazole and 6-methyl-5-epten-2-one generated rancid, metallic, and rubbery odours in the off-season tomatoes, explaining their lower overall acceptability.

Under greenhouse conditions, tomato crops can experience suboptimal $\mathrm{CO}_{2}$ concentrations during daytime (even in the range of 100-250 ppm), due to the hermetic conditions imposed by the shelters $[103,104]$. This can have a negative consequence on plants' assimilation rates, yield potential, and eating quality attributes for many vegetables, including tomatoes [105]. For this reason, $\mathrm{CO}_{2}$ enrichment is a greenhouse technique widespread all over the world, as it allows the promotion of crop yield and accumulation of important fruit constituents, such as sugars, organic acids, vitamins, and carotenoids of phenols $[106,107]$. As many of these compounds are involved (directly or indirectly) in flavour perception, it can be expected that $\mathrm{CO}_{2}$ enrichment could open perspectives for improving the volatilome composition in greenhouse tomatoes. Although this aspect has not yet been sufficiently explored, Zhang et al. [108] reported, through the use of electronic nose and sensory analysis, a distinct aroma profile in 'Jinpeng' tomatoes, positively correlated to the preference of panellists, resulting from greenhouse cultivation under $\mathrm{CO}_{2}$-enriched conditions (800-900 ppm). However, the biochemical determinants of these results seem complex, since different factors (e.g., increased concentrations of sugars, organic acids or carotenoids) may have impacted the preference scores.

Among the microclimate growth conditions, light quantity and quality may play an important role in affecting plant metabolism. Several studies have shown that the composition of the light spectrum has significant effects on the volatile profile of many vegetable crops $[109,110]$. Tinyane et al. [92] evaluated the effects of different shading nets on the volatile profile and sensory attributes of greenhouse tomato cv. 'AlfaV'. To this end, the effects of three coloured shading nets, providing $40 \%$ light reduction (red, yellow and pearl) were compared with a conventional black net (25\% light reduction). The authors reported that tomatoes grown under the red net had a greater number of odour active compounds than the other treatments, as they showed some additional volatile compounds such as 1-penten-3-one, (E)-2-heptenal, nonanal, (E)-2-hexenal, citral and 2,4decadienal. Contrastingly, when grown under the yellow net, tomatoes showed a poorer volatile composition than under the other nets, most of all in terms of 6-methyl-5-hepten-Zone, geranylacetone, (E)-2-octenal and 2-isobutylthiazole. The results were mirrored by the untrained panel test preference, which gave a higher mean sensory score to 'AlfaV' tomatoes obtained under the red net. Significant results were obtained by Lee et al. [84] in comparing a net-house (providing 20-29\% of shading) and an open-field production system, for the cultivation of 8 tomato cultivars including Beefsteak (round type) and Roma (oval type). All tomato varieties showed higher levels of aldehydes, ketones and sulphur volatiles when grown under shading, and 1-penten-3-one, a ketone whose concentration is promoted by sunlight and hydroxyl radicals [111], was higher in open-field, while geranial and neral (susceptible to degradation under UV exposure), were higher under shading. Likewise, linalool, which has been reported as a degradation product of D-limonene as a consequence of UV irradiation [112], was higher in the open field.

\subsection{Growing Medium and Fertilization}

The growing medium appears to be an important factor influencing the expression of the aromatic compounds in tomatoes, as demonstrated by Thybo et al. [98]. These authors studied the sensory quality and volatile response of greenhouse tomato cv. 'Aromata' grown in soil, in confined beds filled with compost, or in a combined bed system (confined beds with lateral holes to allow partial root penetration into the soil). The authors observed 
that both the combined and confined systems produced tomatoes with higher scores for sensory quality, along with a slightly increased level of hexanal, 1-octen-3-one, linalool and $\beta$-cyclocitral and a decrease in dimethyl sulfoxide. They suggested that the healthier root system of tomato plants grown on compost beds was the main trait explaining the detected differences. In another study, Thybo et al. [113] compared the sensory quality of tomatoes grown on soil and Rockwool, highlighting that tomatoes grown on Rockwool were perceived as more "firm" and "crispy", while no difference was reported for "tomato aroma". The studies concerning the effect of the growing medium on the volatile profile of tomato fruits are however few in number, those that have been undertaken often do not integrate sensory analysis with instrumental analysis to support the results obtained, and have focused more on the system as a whole than on the growing medium.

Additionally, crop nutrition has a huge influence on plant growth and development, affecting several qualitative traits of many fruits and vegetables, including VOCs [114]. In an early study conducted by Wright and Harris [99], it has been demonstrated that the increase in $\mathrm{N}$ (from 112 to $336 \mathrm{~kg} \mathrm{ha}^{-1}$ ) and $\mathrm{K}$ supply (from 168 to $504 \mathrm{~kg} \mathrm{ha}^{-1}$ ) decreased the mean flavour scores of 'Walter' tomato fruits, despite the increase in $\beta$-ionone, 6 methyl-5-hepten-2-one, hexenal, 2-hexanone, phenylacetaldehyde, 2,4 hexadienal and benzaldehyde. They argued that the onset of an undesirable flavour in the overfertilized fruits may have been related to the outstanding increases in hexanal, 2-hexanone and 2,4 hexadienal concentrations.

Wang et al. [87] studied the effect of six levels of $\mathrm{N}$ supply in the nutrient solution (from 0 to $36 \mathrm{mmol} \mathrm{L}^{-1}$ ) on greenhouse cherry tomato cv. 'Chuanzhu'. The authors observed simple linear equations describing the positive response of nine flavour contributors to the N supply (namely, 1-penten-3- one, hexanal, cis-3-hexenal, 2-methyl-4-pentenal, trans-2- hexenal, 6-methyl-5-hepten-2-one, titratable acidity, soluble sugars, and soluble solids), whereas power-law equations described the response of phenylacetaldehyde and phenylethanol, and quadratic equations described the trend of 2E-4E-hexadienal and firmness. The authors assumed that a moderate $\mathrm{N}$ supply improves tomato flavour, whereas an excessive supply can have the opposite effect. In an analogous experiment, the same authors reported that a moderate $\mathrm{K}$ concentration in the nutrient solution (between 1.7 and $4.8 \mathrm{mmol} \mathrm{L}^{-1}$ ) improved the concentration of 3-methyl-butanal, 1-penten-3-one, hexanal, cis-3-hexenal, 2-methyl-4-pentenal, trans-2-hexenal, 2E-4E-hexadienal, 6-methyl-5-hepten2-one, phenylacetaldehyde, and phenylethanol, hence demonstrating the deleterious effects of the overuse of $\mathrm{K}$ on tomato volatile profile [88].

\subsection{Irrigation and Water Quality}

Several irrigation techniques have been proposed to improve the quality traits of tomatoes, such as deficit irrigation [115], partial root drying [116] or irrigation with salt water [117]. Nevertheless, studies on the influence of irrigation on tomato VOCs are still scarce. Among the few examples, Veit-Köhler et al. [89] found that a reduced water supply improved the overall flavour of 'Vanessa' tomatoes. In particular, by applying two irrigation regimes, namely an optimal one $(70 \%$ of the water-holding capacity of the soil) and a reduced one (water-holding capacity at 50\%), the authors found in the latter, an increased concentration of four C6 aldehydes, namely, hexanal, (Z)-3-hexenal, (E)-2-hexenal and benzaldehyde (by up to $21 \%, 61 \%, 22 \%$ and $15 \%$, respectively). More recently, Lahoz et al. [21] conducted a 2-year study on the effects of deficit irrigation on the aroma profile of four processing-tomato cultivars, i.e., 'H-9036', 'H-9661', 'Kalvert' and 'Loralie'. Three irrigation regimes were applied, i.e., by restituting 75\%, 100\% and 125\% of crop evapotranspiration (ETc), by means of drip irrigation. The author reported that in the first year, deficit irrigation increased the log odour units of almost all the 33 main aroma volatiles, especially those of geranylacetone, (Z)-3-hexenol and (E, E)-2,4-decadienal, compared to the other treatments. On the other hand, the $100 \%$ ETc restitution increased the level of (E, E)-2,4-decadienal whereas the 125\% restitution had a dilution effect for the main volatile compounds. 
An increased electrical conductivity (EC) in irrigation water is often associated with improved quality traits of tomato fruit such as taste, flavour and the presence of bioactive compounds [118]. Dorais et al. [95] studied the effects of the increased EC of the nutrient solution (from 1.8 to $5.0 \mathrm{mS} \mathrm{cm}{ }^{-1}$ ), obtained by adding either $\mathrm{NaCl}$ or $\mathrm{NaCl}+\mathrm{KCl}$, in greenhouse 'Blitz' tomato. When compared to a control, the increased EC boosted the concentration of the main detected volatiles, i.e., 3-methyl butanol (+63\%), trans-2-hexenal $(+48 \%)$ and hexanal $(+22 \%)$, irrespective of the salt used. More recently, Cliff et al. [119] reported that tomatoes produced at different EC levels of the nutrient solution (low $0.2 \mathrm{~S}$ $\mathrm{m}^{-1}$, medium $0.35 \mathrm{~S} \mathrm{~m}^{-1}$ or high $0.5 \mathrm{~S} \mathrm{~m}^{-1}$ ) were characterized by different sensory quality traits, with the high EC solution generating the best perception in terms of "tomato taste", "sweet taste", "firmness-by-mouth" and "tomato aroma".

\subsection{Plant-Beneficial Microorganisms}

In the last decades, increasing concerns about the rise in world population and agricultural side-effects on ecosystems and human health have prompted agronomic research to create more productive and sustainable agricultural and food systems [120-122]. In this view, the exploitation of specific plant-beneficial microorganisms (PBMs) populating the rhizomicrobiome, such as arbuscular mycorrhizal (AM) fungi or plant-growth-promoting rhizobacteria (PGPR) have proved relevant in experimental results related to improving the efficiency of plant nutrition processes, resilience toward environmental stressors and accumulation of nutraceuticals in the edible portions [123-126]. During the establishment of the plant-microbe symbiosis, plants respond to root infection by up-regulating multiple metabolic patterns, including those involving a systemic modification of volatile biosynthesis [127]. Thus, the exploitation of specific PBMs (e.g., by utilizing microbial biostimulants) could open interesting perspectives to obtain more flavorful tomatoes, although the results do not always seem consistent. Among the most significant contributions, Hart et al. [90] found that inoculated tomato plants of the 'Moneymaker' variety with AM fungi (Rhizophagus irregularis and Funneliformis mosseae, alone or in combination) produced fruits with enhanced phenylalanine (1-nitro-2-phenylalanine, guaiacol and methyl salicylate), leucine (1-nitro-3-methylbutane) and carotenoid-derived volatiles (6-methyl-5-hepten-2-one and geranylacetone). The authors attributed the increase in phenylalanine-derived volatiles to the up-regulation of the phenylpropanoid pathway, producing, in turn, an array of antioxidant compounds modulating the plant's response to root colonization by the AM fungi. Such an interpretation seems coherent with the results of Ruiz-Cisneros et al. [96] who subjected the greenhouse tomato 'Merlice' to a root application of Bacillus amyloliquefaciens, B. methylotrophicus and B. subtilis, alone or in combination. The authors reported a PGPR-derived increase in fruit concentration of volatiles having a role as antimicrobials (2-hexenal) or in systemic acquired resistance by the plant (methyl salicylate), together with enhanced concentrations of carotenoids, phenolic acids and associated volatiles. On the other hand, Pasković et al. [93], by applying commercial microgranules of R. irregularis to 'Red Valley H1' tomatoes, noticed poorer fruit concentrations in terms of fatty acid (1-hexanol, 1-penten-3-ol) and amino acid derivatives (1-pentanol (n-amyl alcohol), 3-methyl-2-butanol or 3-methyl-1-butanol). Overall, understanding to what extent these modifications impact tomato eating quality still remains elusive, together with the role of 'cultivar-microorganism(s)-environment' interactions in dictating the volatilome reconfiguration of tomatoes. Due to their complex nature, such determinants could be challenging with regards to using PBMs to improve tomato flavour, at least in the mid-term.

\subsection{Harvest Stage}

Fruit ripening is a non-reversible, genetically programmed process, resulting in profound modifications of the textures, colours, flavours, tastes and aromas of fruit flesh [69]. The synthesis of volatiles is quantitatively and qualitatively different during the various ripening stages of tomatoes, since their concentration rises during the onset of ripening, peaking at full maturation [128,129]. Indeed, as previously reported by Galliard et al. [130], 
the activities of several enzymes seem to change during ripening, especially those involved in the formation of lipid-degraded products, such as (E)-2-hexenal and (Z)-3-hexenol [130]. However, specific commercial requirements (improved shelf life and tolerance to physical damages during postharvest handling) prompt farmers to anticipate fruit harvesting, with subsequent modifications of the aroma metabolism [131]. This was already evident in the pioneering work of Wang et al. [101], who profiled the aroma composition of field-grown tomatoes 'V. R. Moscow' reaching the red-ripe stage either on the plant or during postharvest. Early harvested tomatoes showed a poorer volatile profile, most of all in terms of isopentyl acetate, isopentenol, benzaldehyde and n-hexyl hexanoate, likely because of a lower concentration of volatile precursors. Similarly, Baldwin et al. [91] demonstrated that, except for eugenol, fruits of 'Sunny' and 'Solar Set' tomatoes harvested at different stages (from mature-green to red) showed an increased concentration of volatiles as ripening proceeded, with some of them (e.g., cis-3-hexenol, cis-3-hexenal, trans-2-hexenal, 6methyl-5-epten-2-one and 2-isobutylthiazole) mirroring the climacteric rise of the ethylene biosynthesis. Du et al. [102] quantified the sulphur volatile compounds in 'Tasti-Lee' and 'FL 47' harvested at the breaker, turning, or pink-ripening stage, showing deep differences. 'FL 47' had a higher level of total sulphur volatile compounds than 'Tasti-Lee', whereas, for both cultivars, the fruits harvested at the turning stage had the highest sulphur volatile content, most of all in terms of dimethyl disulphide, dimethyl trisulphide, 2-isobutylthiazole and methional.

Klein et al. [100] characterized the influence of two harvest times, namely 'optimal' and 'early' (4 days before) on the flavour compounds of four tomato genotypes ('Ananas', 'Auriga', 'Green Zebra' and 'Lukullus'). The results showed that, at the optimal harvest time, two of the genotypes under study, namely 'Auriga' and 'Lukullus' showed the highest content of the carotenoid-derived volatile 6-methyl-5-hepten-2-one, consistent with their increase in lycopene content during ripening.

\section{Postharvest Factors Affecting Tomato Volatiles}

During postharvest life, the metabolism of climacteric fruits like tomatoes generates relevant modifications of the overall product composition [132]. Postharvest handling and storage have a key role in interfering with fruit metabolism, and this inevitably impacts the constituents responsible for flavour perception [17] (Table 4). Therefore, in-depth knowledge about the effects of postharvest conditions and technologies on fruits and vegetables plays a fundamental role to avoid undesirable compositional and organoleptic alterations of the fruit along the food chain [133]. This is particularly important for tomatoes, for which spatial and temporal gaps between production and consumption often impose long periods of transport and postharvest storage [134]. 
Table 4. Significant variations of main volatile compounds found in tomatoes in relation to postharvest factors.

\begin{tabular}{|c|c|c|c|c|}
\hline Volatile Compounds & $\begin{array}{l}\text { Microclimate Storage } \\
\text { Conditions }\end{array}$ & $\begin{array}{l}\text { Storage Atmosphere } \\
\text { Composition }\end{array}$ & $\begin{array}{c}\text { Postharvest Chemicals } \\
\text { Application }\end{array}$ & Industrial Processing \\
\hline \multicolumn{5}{|l|}{ Fatty acid derivates } \\
\hline $\begin{array}{l}\text { Hexanol } \\
\text { Z-3-Hexenal } \\
\text { E-2-Heptenal } \\
\text { 1-Penten-3-ol } \\
\text { Pentanol } \\
\text { E-2-Pentenal } \\
\text { Z-3-Hexenol } \\
\text { E-2-Hexenal } \\
\text { 1-Penten-3-one } \\
\text { Hexanal } \\
\text { Caroteoid derivates }\end{array}$ & $\begin{array}{c}{[17,22,135]} \\
{[141]} \\
{[17,22,135]}\end{array}$ & [143] & $\begin{array}{c}{[136,137]} \\
\\
{[136]} \\
{[137]} \\
{[142]} \\
{[136,137]} \\
{[142]} \\
{[144]}\end{array}$ & $\begin{array}{c}{[138,139]} \\
{[64,138,139]} \\
{[64]} \\
{[138]} \\
{[138]} \\
{[139]} \\
{[64,139]} \\
{[64]} \\
{[64,139]}\end{array}$ \\
\hline $\begin{array}{l}\text { Epoxy- } \beta \text {-ionone } \\
\text { Pseudoionone } \\
\beta \text {-Damascenone } \\
\text { Neral } \\
\beta \text {-Cyclocitral } \\
\beta \text {-Ionone } \\
\text { Geranial } \\
\text { Geranylacetone } \\
\text { 6-Methyl-5-hepten-2-one } \\
\text { Amino acid derivates }\end{array}$ & $\begin{array}{l}{[141]} \\
{[22]} \\
{[22]}\end{array}$ & $\begin{array}{l}{[145]} \\
{[145]} \\
{[145]} \\
\\
{[145]}\end{array}$ & $\begin{array}{c}{[136,137]} \\
{[142]} \\
{[136,137,142,144]} \\
{[136,142,144]}\end{array}$ & $\begin{array}{c}{[64]} \\
{[138]} \\
{[138]} \\
{[64,138,139]}\end{array}$ \\
\hline $\begin{array}{l}\text { 3-Methylbutanenitrile } \\
\text { 2-Phenylacetaldehyde } \\
\text { 1-Nitro-2-phenylethane } \\
\text { 3-Methylbutanal } \\
\text { 2-Isobutylthiazole } \\
\text { Methyl salicylate } \\
\text { 3-Methylbutanol } \\
\text { 2-Phenylethanol } \\
\text { Others }\end{array}$ & $\begin{array}{c}{[22]} \\
{[17,22,141]} \\
{[141]} \\
{[135,140]} \\
{[141]}\end{array}$ & $\begin{array}{c}{[143]} \\
{[143,144]}\end{array}$ & $\begin{array}{c}{[142]} \\
{[144]} \\
{[137,142]} \\
{[137,142]} \\
{[142]} \\
{[137]}\end{array}$ & $\begin{array}{c}{[64]} \\
\\
\\
{[64]} \\
{[138]} \\
{[64]} \\
{[138]}\end{array}$ \\
\hline $\begin{array}{l}\text { Linalool } \\
\text { 1-Nitro-3-methylbutane }\end{array}$ & & & & {$[64,138]$} \\
\hline
\end{tabular}

\subsection{Microclimate Storage Conditions}

Refrigerated storage represents the core technique to extend the postharvest life of tomatoes [146] since, for every $10^{\circ} \mathrm{C}$ increase in storage temperature above the optimum threshold, the rate of fruit deterioration can increase 2-3 fold [147]. The most common thermal regime to store tomatoes falls between 10 and $15^{\circ} \mathrm{C}$ [148], with differences related to both technical (e.g., storage duration) and biological factors (e.g., ripening stage or fruit typology). However, these commercial regimes often do not correspond to those that are best for preserving the components involved in aroma perception, so, recently Zou et al. [149], through a volatile-related transcriptome analysis, questioned the validity of storing tomatoes at the recommended temperature of $10{ }^{\circ} \mathrm{C}$. In this sense, it must be considered that most commercial storage recommendations have been framed around the use of threshold temperatures that do not induce the development of visual chilling injury (CI) symptoms, or alteration of the main compositional traits [150], with obvious limitations in the perspective of preserving the aroma compounds. Indeed, because of the tropical origin of the species, tomato fruits are prone to chilling stress already below $13{ }^{\circ} \mathrm{C}$ [144], and the typical CI symptoms (e.g., uneven ripening and colour distribution, softening, worsened fruit appearance, and increased microbial decay) are usually preceded by the alteration of the metabolism of glucose and aroma compounds [148]. Storage temperature and duration are the main effectors of aroma evolution during the life of postharvest fruit. By storing 'Solimar' and 'BNH-189' tomatoes for 8 or 12 days, Maul et al. [22] reported that temperatures below $12.5^{\circ} \mathrm{C}$ promoted off-odours and progressive depletion of key odorants such as acetaldehyde, hexanal, trans-2-hexenal, 6-methyl-5-epten- 
2-one and geranylacetone. Similar results were reported by Ponce-Valadez et al. [135] in ' $7705^{\prime}$ tomatoes. The authors stored the fruits at 12.5 or $20.0{ }^{\circ} \mathrm{C}$ for up to 15 days and found that the lower temperature inhibited the activity of alcohol dehydrogenase (ADH) alongside the overall volatile concentration (mainly hexanal, hexanol, and 3-methylbutanol), despite a transitory increase of trans-2-hexenol after 9 days of storage. On the other hand, Farneti et al. [17] demonstrated the importance of fruit typology in profiling the volatile response to the storage conditions. The authors noticed in red ripe tomatoes 'Cappricia' (round truss) and 'Amoroso' (cocktail truss), stored for 20 days either at 16 or $4{ }^{\circ} \mathrm{C}$, an increased concentration of some carotenoid-derived volatiles (such as geranylacetone and $\beta$-ionone) in the 'Cappricia' but not in the 'Amoroso' types, probably as a consequence of their different postharvest ripening processes. Moreover, the lower storage temperature induced a progressive depletion of the aldehydes hexanal and trans-2-hexanal, which was particularly severe in 'Cappricia' tomatoes.

Relative humidity $(\mathrm{RH})$ in the storage environment seems to affect the aroma components of fresh tomatoes as well. The volatile composition of red-ripe fruits $\mathrm{cv}$. 'Caramba' were evaluated by Raffo et al. [141] after storing them for 7 days at $6{ }^{\circ} \mathrm{C}$ in a conventional refrigeration system $(55-80 \% \mathrm{RH})$ or a passive refrigeration system $(98 \pm 0.5 \% \mathrm{RH})$. The aroma profile of fruits stored under higher, less fluctuating $\mathrm{RH}$ conditions showed, among others, increased levels of trans-4,5-epoxy-(E)-2-decenal (+69\%), 2-phenylethanol (+67\%), 1-penten-3-one $(+66 \%)$ and (E)-2-hexenal $(+56 \%)$, but lower concentrations of 6-methyl-5hepten-3-one $(-83 \%)$, methyl salicylate $(-54 \%)$, methional $(-52 \%)$ and $\beta$-ionone $(41 \%)$, hence highlighting the huge complexity underpinning the interactions among fruit volatile constituents and the physical characteristics of the storage environment.

It is well known that in vegetables, light quantity, duration, and spectral composition influence both product quantity and shelf life [151]. Nonetheless, there are few examples of postharvest light manipulation being used as a tool to improve tomato aroma volatiles. Among the few examples, Colquhoun et al. [140], by using field-grown tomatoes cv. 'M82' harvested at breaker stage, evaluated the effects of four LED light compositions provided to fruits for 10 days during postharvest ripening, on the emission of cis-3-hexenal, cis-3hexen-1-ol, 2-methyl butanal, and 3-methyl-1-butanol. The light treatments were white (cool white fluorescent bulbs), blue $(455 \mathrm{~nm})$, red $(668 \mathrm{~nm})$, and far-red $(755 \mathrm{~nm})$, each provided with the same intensity $\left(50 \mu \mathrm{mol} \mathrm{m} \mathrm{m}^{-2} \mathrm{~s}^{-1}\right)$ and compared to dark stored fruits. When compared to the white light, the far-red treatment enhanced the emission of all four volatiles, whereas keeping the fruits in the darkness promoted the concentration of cis-3-hexenol, 3-methyl-butanol and 3-methyl-butanal. The red light improved the emission of 2-methyl butanal and 3-methyl-1-butanol. No significant differences were observed among the blue and white light treatments. These findings are important because of the possibility to enhance, using red or far-red light, the concentration of volatiles involved in sweetness perception and overall product acceptability.

\subsection{Storage Atmosphere Composition}

A controlled atmosphere (CA), a modified atmosphere (MA), and modified atmosphere packaging (MAP) are common techniques to extend the shelf life of vegetables and to preserve as long as possible their common organoleptic traits [152,153]. However, until now, these techniques have not always shown adequate results in order to preserve the aromatic profile of tomatoes, because of the stress induced by the altered atmospheric composition on volatiles' biosynthetic pathways [154,155].

In an early report on CAs, Ratanachinakorn et al. [156] studied the effects of flowthrough humidified gas exposure $(70 \% \mathrm{RH})$ containing $21 \% \mathrm{O}_{2}$, and $0.5 \% \mathrm{O}_{2}+\mathrm{N}_{2}$ for 1 day, or $80 \% \mathrm{CO}_{2}+$ air for 1 or 2 days on postharvest fruit ripening and peak production of ethanol and acetaldehyde, as well as on the sensory profile of tomatoes cv. 'Bermuda'. Fruits were picked at the mature-green, breaker or pink-ripening stages, exposed to flowthrough treatments from the same day as harvest, then transferred to air to reach the table-ripe stage. The authors observed a delay of up to 2 days in fruit ripening after 
exposure to low $\mathrm{O}_{2}$ or high $\mathrm{CO}_{2}$ flow-through, with the low $\mathrm{O}_{2}$ treatment also promoting higher production of ethanol and acetaldehyde, most of all in the breaker and pink-ripe fruits. The authors attributed the increase in volatile production in fruits with advanced maturity to the higher activity of alcohol dehydrogenase (ADH). Nevertheless, none of the $\mathrm{CA} /$ ripeness combinations under study enhanced the aroma and taste of the fruits, so the authors concluded that these short-term postharvest techniques cannot be used to reliably improve their sensory quality. In another experiment, Deltsidis et al. [145] stored pink-ripe 'Tasti-Lee' tomatoes in air (control) and $\mathrm{CA}$ with different $\mathrm{O}_{2}: \mathrm{CO}_{2}$ ratios (from 12:4 to $3: 8 \mathrm{kPa}$ ), at $12.5,15.0$ and $18.0^{\circ} \mathrm{C}$. The fruit volatile profile was assessed soon after harvest and after 5 and 10 days of CA storage, either with or without a further 2 days of shelf life in air at $20^{\circ} \mathrm{C}$, to simulate the maximum shipping plus storage in the US market. The authors reported a retarded ripening and a prolonged storage period in long-term CA-stored fruits, which was paralleled by a reduction in their total volatiles. The suppressive effect of the elevated $\mathrm{CO}_{2}$ concentration in the storage atmosphere appeared particularly evident for 6-methyl-5-hepten-2-one. Moreover, no temperature effect was recorded on CA stored fruits that were kept at 15 or $18{ }^{\circ} \mathrm{C}$ for 10 days, indicating overall that $\mathrm{CA}$ inhibited the production of volatiles more than temperature did.

In a study concerning MA, Boukobza and Taylor [143] stored tomato fruits cv. 'Solairo' for up to $35 \mathrm{~h}$ at room temperature either in normal air (control) or in a N atmosphere with further addition of $5 \% \mathrm{O}_{2}+10 \% \mathrm{CO}_{2}$. After $48 \mathrm{~h}$ of acclimatization in air, MA stored fruits showed a decreased concentration of the odour-active volatiles hexanal $(-65 \%)$, methylbutanal $(-54 \%)$ and isobutylthiazole $(-64 \%)$ as compared to those stored in a normal atmosphere, hence denoting their persistent metabolic impairment for attaining full recovery of key aroma compounds. On the other hand, Bailén et al. [157] reported promising results by using the active MAP technology to preserve tomato quality and flavour profile during postharvest storage. The authors kept tomato fruits cv. "Beef" for up to 28 days $\left(8^{\circ} \mathrm{C}, 90 \% \mathrm{RH}\right)$ in selectively permeable plastic bags alone (control), or containing granular activated-carbon (GAC), either alone or in combination with palladium (GAC$\mathrm{Pd})$, to reduce the ethylene accumulation inside the packages. The addition of ethylene absorbers, and especially GAC-Pd, efficiently reduced the ethylene accumulation inside MAP packages, allowing a more convenient equilibrium between $\mathrm{O}_{2}$ and $\mathrm{CO}_{2}$ concentration once the steady-state package-atmosphere composition was reached. Consequently, some parameters related to fruit ripening such as changes in colour, softening, and weight loss evolved more slowly in tomatoes packaged with GAC or GAC-Pd, with a resultant lower product spoilage at the end of the storage period. Despite the higher volatile occurrence in the internal atmosphere of control bags, the quality of GAC and GAC-Pd packaged fruits was judged better by panelists in terms of odour and flavour. The authors explained this apparent contradiction through the higher incidence of 2-methylbutanol (over 40\%) in the active MA packages, given the pivotal contribution of this leucine-derived volatile in conferring sweet/fresh notes to tomato flavour.

\subsection{Postharvest Chemicals Application}

Several chemical treatments can influence the postharvest metabolism of tomato fruits, so their use in improving the postharvest shelf-life has been extensively studied [146]. Since tomato aroma metabolism occurs in a ripening-dependent manner, chemical applications either promoting or inhibiting ripening have proven effects on fruit volatile profiles [88]. However, their large-scale adoption, as any postharvest chemical has to pass through sound quantifications regarding their effects on the ripening process and volatile profile of the fruit.

As a main driver of the ripening process, ethylene generates relevant modifications in tomato quality during postharvest, and its application to synchronize the fruit ripening process is a widespread postharvest technique [26], despite the detrimental effects on tomato aroma that have been noticed [144]. On the other hand, the application of its main antagonist 1-methylcyclopropene (1-MCP) has proven to be a valuable postharvest tool 
to improve the shelf life and some quality traits of ripe tomatoes [158]. However, the fact that some volatiles can be unaffected while others even diminished from the use of 1-MCP makes a sound prediction of the impact of this growth regulator on tomato aroma difficult [159].

Salicylic acid (SA), jasmonic acid (JA), and their methyl esters (MeSA and MeJA) represent endogenous signal molecules involved in regulating the plant response to external stressors [160], and their exogenous application has been used as a postharvest tool to modulate tomato ripening, but variable responses were recorded on tomato aroma components. In unchilled 'FL 47' tomatoes treated either with $0.05 \mathrm{mM}$ MeSA or MeJA, Wang et al. [142] found a reduced concentration of aroma contributors such as cis-3-hexenal, D-limonene, and 6-methyl-5-hepten-2-one $(-11 \%,-40 \%$ and $-87 \%$, respectively), which was opposite to 'FL 47' chilled fruits. Moreover, a panel test revealed a positive effect of MeSA treatment on tomato aroma only in chilled tomatoes, overall highlighting strong interactive effects with the storage conditions.

Over the last few years, the advances in metabolomic tools have improved the understanding of modifications in the ripening process that are brought about by the application of exogenous chemicals. As a consequence, a growing amount of information is becoming available to dissect the molecular basis underpinning the shelf-life and postharvest aroma evolution of tomatoes in response to exogenous phytohormones. To this end, in cherry 'Xin Taiyang' tomatoes infiltrated with 1mM abscisic acid (ABA) Wu et al. [136] noticed a faster ripening process, consistent with their more sustained ethylene production, together with an enhanced expression of TomloxC, HPL, ADH2, and LeCCD1B genes, which paralleled the increased concentration of the associated fatty-acid-derived volatiles (trans-2-hexenal, pentanal, 1-hexanol and 1-penten-3-ol) or carotenoid-derived volatiles (6-methyl-5-hepten-2-one, geranylacetone and pseudoionone). By applying a similar approach, Wu et al. [137], in fruits of the same cultivar treated with a $0.45 \mathrm{mM}$ aqueous solution of 2,4-dichlorophenoxyacetic acid (2,4-D) detected an improved postharvest fruit appearance, but a decreased expression of TomloxC, HPL, ADH2 and LeCCD1B, which was accompanied by some decreased concentrations of fatty-acid- and carotenoid-derived volatiles (including geranylacetone, $\beta$-ionone and pseudoionone), highlighting the molecular basis for the inhibitory effects of exogenous auxin on key volatiles during tomato postharvest fruit ripening.

\section{Industrial Processing}

Industry-type tomatoes are specific varieties with a thick, fleshy pericarp and a small portion of gel. When subjected to processing, most are pureed and then concentrated for subsequent use as ingredients in many preparations [161]. The most common tomato processing technique consists of fruit-washing, chopping and immediate heating. On one hand, "cold break" (CB) juices are initially heated to around $70{ }^{\circ} \mathrm{C}$, i.e., the temperature at which pectinolytic enzymes liquefy the products. Then the enzymes are inhibited by stabilizing treatment (around $10 \mathrm{~min}$ at $95^{\circ} \mathrm{C}$ ). On other hand, "hot break" (HB) juices are directly heated at $95{ }^{\circ} \mathrm{C}$ to quickly inhibit the liquefying enzymes, maintaining the natural viscosity of the purees. The pulp is then refined to remove the skin and seeds, and concentrated at a low temperature (between 40 and $50{ }^{\circ} \mathrm{C}$ ) under vacuum, to avoid additional cooking. The product is either directly packaged by hot-filling (at around $80-95{ }^{\circ} \mathrm{C}$ ), or canned and sterilized again. Alternative processes also produce peeled tomatoes in juice, peeled and crushed tomatoes to make sauces with a coarser texture, or peeled, diced and canned in juice to serve as ingredients in dishes [161]. Each operation strongly affects the organoleptic quality of fresh tomatoes. Using solvent extraction techniques, Buttery et al. [63] compared the concentration of VOCs in fresh or pureed fruits. The first difference was a massive disappearance of most of the C6 compounds resulting from the oxidation of lipids, including a decrease from 12,000 to $0.7 \mathrm{ppb}$ in (Z)-3-hexenal, or from 3100 to $0.7 \mathrm{ppb}$ for hexanal. On the contrary, the concentration of dimethyl sulphide (DMS) increased (from 0 to $2000 \mathrm{ppb}$ ). The production of DMS is a result of the conversion of free 
S-methionine [64]. This conversion reaches a high speed when the temperature exceeds $80{ }^{\circ} \mathrm{C}$. The disappearance of the main aroma compounds makes the influence of some secondary volatiles (e.g., eugenol, 6-methyl-5-hepten-2-one, $\beta$-damascenone or $\beta$-ionone) more important for the overall aroma perception in processed tomatoes [64].

The modifications of VOCs in processed products can be explained by four coupled phenomena. (i) The rapid evaporation of most volatiles due to thermal treatments (as in the cases of (Z)-3- hexenol or hexenal). (ii) The relative stability of less volatile compounds, such as 6-methyl-5-hepten-2-one, and the subsequent increase of their influence on the overall aroma [64]. (iii) The appearance of newformed products under the effect of heating, like furfural, which originates from the Maillard reaction and is characteristic of the HB products [138]. (iv) Enhanced enzymatic reactions when processing temperatures increase (but stay below denaturation temperatures) and/or when the process breaks the cellular integrity of the tomatoes and then brings the enzymes close to their substrates.

The release of $\mathrm{C} 6$ volatiles (like (Z)-3-hexenol or hexenal) by lipoxygenase is the major reaction that occurs, even if those VOCs are then partially lost because of their thermal instability. Thus, $\mathrm{CB}$ juices exhibit a higher content of $\mathrm{C} 6$ volatiles when compared to the $\mathrm{HB}$ ones, but these are still far from the levels observed in fresh fruits [138]. The other class of enzyme-released VOCs comes from the glycoconjugates, which are VOCs rendered non-volatile by being grafted onto glycoside units during fruit ripening, and which are then stored in the vacuole. This aromatic reserve, which can be up to twice the concentration of free VOCs [31] is released when loss of cell integrity brings the cytoplasmic glycosidases in contact with the glycoconjugates and triggers the release of their volatile moieties [162]. VOCs such as eugenol or $\beta$-damascenone detected in most processed products come from this mechanism [63]. Based on the odour thresholds, the typical "cooked tomato" aroma could be limited to the contributions of 7 major molecules: dimethyl sulphide, 3-methylbutyric acid, eugenol, 1-nitro-2-phenylethane, methional (3-(methylthio) propanal), 3-methylbutanal and $\beta$-damascenone [63]. However, studies carried out by Tieman et al. [35] on fresh tomatoes indicate strong synergistic effects existing between molecules, which may modify their perception. DMS, which has been recently identified in fresh tomatoes too [102], is generally described as an off-flavour contributor, but according to Guadagni et al. [163] is also known as a booster of fresh tomato aroma. On the other hand, recently Jeyaprakash et al. [164] have positively correlated the DMS concentration to the tinned tomato flavour and negatively to fresh tomato flavour. This indicates a variable contribution of this compound to the overall tomato flavour, likely as a consequence of complex interactions with other molecules, both volatile and non-volatile [163]. The quantification methods should require attention to this in analyses of processed tomatoes, as DMS is generally not detected by solid-phase microextraction methods (SPME) used in most recent studies $[165,166]$.

Innovative processing methods have a significant impact on aromatic compounds in tomato products compared to traditional ones. The use of high-pressure processing (HPP) for stabilizing a cherry tomato puree resulted in an improved VOCs profile [139]. HPP results in a VOC profile closer to fresh tomato than high-temperature short-time treatment (HTST) [3]. Interestingly, HTST was the only treatment where DMS was detected. When high-pressure is combined with heat treatment $\left(800 \mathrm{mPa}\right.$ and $\left.80^{\circ} \mathrm{C}\right)$, a strong odour of "cooked tomato" and "green tea" (off-flavor) occurred. Other authors demonstrated that under these conditions, lipoxygenase and hydroperoxide lyase (responsible for C6 volatiles formation) are strongly affected [167]. The use of Pulsed Electric Fields (PEF) reduces the requirement of intense heat treatments to manage microbial proliferation. This results in juices richer in "fresh tomato" compounds [168]. PEF strongly inhibits residual oxidative activity and allows longer preservation of the aromatic profile.

The complete mechanism controlling the aroma of cooked products is far from being fully understood. To our knowledge, no systematic studies are available on the processing of tomato mutants for the main enzymes involved in aroma release, and identification of correlations among molecules with sensory attributes of cooked products is still lacking. It 
may help to measure the real impact of individual molecules and their interactions [35]. The confrontation of such results with genetic maps should help to identify physiological functions involved in odour modification during industrial processing. This should improve the breeding strategy for industry-type tomatoes leading to more aromatic products, as was achieved for fresh fruits [18].

\section{Conclusions and Future Perspectives}

Improving flavour is currently a crucial challenge to satisfy consumers' requests and to further consolidate tomato consumption on a global scale, going far beyond a merely hedonistic target. The growing genetic knowledge about the expression of volatile compounds is going to open new ways for regulating their related biosynthetic pathways, making it possible to generate novel products with unprecedented sensorial profiles. However, due to their multifactorial nature, improving tomato volatiles will inevitably have to deal with the influence of external factors (environmental conditions, crop management practices, postharvest technologies and processing) generating ample variability in many key quality traits of tomatoes. Thus, improving tomato flavour means better understanding these interactions in order to propose targeted breeding strategies, pre and postharvest management, or processing methods that significantly impact consumers' preferences. In this view, coupled sensory analysis and metabolomic approaches, as achieved on fresh fruits, demonstrated that strong molecular interactions occur among volatiles, questioning the paradigm of concentration/odour threshold theory, which is generally acknowledged to explain the molecular basis of aromatic sensation. Thus, future research will have to face the existing relationships linking technical factors, volatilome remodeling and consumers' response, taking into account, also, the inherent typological complexity of characterizing both fresh (e.g., cherry, plum, beef, round tomatoes and so on) and processed products (e.g., purees, juices, sauces and so on).

With few exceptions, our knowledge about the metabolic and molecular effects of pre and postharvest factors, influencing tomato flavour and related consumers' response is still scarce, making it difficult to draw sound conclusions to best manage the future genetic potential. Given the complexity of the task, the path towards reliable operational indications still seems long. In this sense, greater integration between agronomy, postharvest technology and sensory evaluations, together with the most advanced plant omics tools, to pursue this triple objective of maximizing yields, improving the sensorial profile of the product and ensuring its adequate shelf life, which is seemingly conflictive, is needed.

Author Contributions: Conceptualization, R.P.M., M.D. and C.L.; methodology, R.P.M. and M.D.; investigation, M.D., R.P.M. and D.P.; proof of concept, C.L., F.G. and N.B.; writing-original draft preparation, M.D., R.P.M. and D.P.; writing-review and editing, R.P.M., C.L., F.G. and N.B.; supervision, C.L. All authors have read and agreed to the published version of the manuscript.

Funding: This research received no external funding.

Institutional Review Board Statement: Not applicable.

Informed Consent Statement: Not applicable.

Data Availability Statement: Not applicable.

Conflicts of Interest: The authors declare no conflict of interest.

\section{References}

1. Food and Agriculture Organization of the United Nations (FAO). Available online: http://www.fao.org/faostat/en/\#home (accessed on 26 January 2022).

2. Mauro, R.P.; Lo Monaco, A.; Lombardo, S.; Restuccia, A.; Mauromicale, G. Eradication of Orobanche/Phelipanche spp. seedbank by soil solarization and organic supplementation. Sci. Hortic. 2015, 193, 62-68. [CrossRef]

3. Wang, X.; Chen, F.; Ma, L.; Liao, X.; Hu, X. Non-volatile and volatile metabolic profiling of tomato juice processed by highhydrostatic-pressure and high-temperature short-time. Food Chem. 2022, 371, 131161. [CrossRef] [PubMed] 
4. $\quad$ Ali, M.M.; Shafique, M.W.; Gull, S.; Naveed, W.A.; Javed, T.; Yousef, A.F.; Mauro, R.P. Alleviation of heat stress in tomato by exogenous application of sulfur. Horticulturae 2021, 7, 21. [CrossRef]

5. Wang, D.; Seymour, G.B. Tomato flavor: Lost and found? Mol. Plant 2017, 10, 782-784. [CrossRef] [PubMed]

6. Chaudhary, P.; Sharma, A.; Singh, B.; Nagpal, A.K. Bioactivities of phytochemicals present in tomato. J. Food Sci. Technol. 2018, 55, 2833-2849. [CrossRef]

7. Bertin, N.; Génard, M. Tomato quality as influenced by preharvest factors. Sci. Hortic. 2018, 233, 264-276. [CrossRef]

8. Bai, Y.; Lindhout, P. Domestication and breeding of tomatoes: What have we gained and what can we gain in the future? Ann Bot. 2007, 100, 1085-1094. [CrossRef]

9. Klee, H.J. Improving the flavor of fresh fruits: Genomics, biochemistry, and biotechnology. New Phytol. 2010, 187, 44-56. [CrossRef]

10. Baldwin, E.A.; Scott, J.W.; Shewmaker, C.K.; Schuch, W. Flavor trivia and tomato aroma: Biochemistry and possible mechanisms for control of important aroma components. HortScience 2000, 35, 1013-1022. [CrossRef]

11. Baldwin, E.A.; Goodner, K.; Plotto, A. Interaction of volatiles, sugars, and acids on perception of tomato aroma and flavor descriptors. J. Food Sci. 2008, 73, S294-S307. [CrossRef]

12. Kyriacou, M.C.; Rouphael, Y. Towards a new definition of quality for fresh fruits and vegetables. Sci. Hortic. 2018, 234, 463-469. [CrossRef]

13. Carli, P.; Barone, A.; Fogliano, V.; Frusciante, L.; Ercolano, M.R. Dissection of genetic and environmental factors involved in tomato organoleptic quality. BMC Plant Biol. 2011, 11, 58. [CrossRef] [PubMed]

14. Petró-Turza, M. Flavor of tomato and tomato products. Food Rev. Int. 1986, 2, 309-351. [CrossRef]

15. Klee, H.J.; Tieman, D.M. Genetic challenges of flavor improvement in tomato. Trends Genet. 2013, 29, 257-262. [CrossRef] [PubMed]

16. Causse, M.; Buret, M.; Robini, K.; Verschave, P. Inheritance of nutritional and sensory quality traits in fresh market tomato and relation to consumer preferences. J. Food Sci. 2003, 68, 2342-2350. [CrossRef]

17. Farneti, B.; Alarcón, A.A.; Papasotiriou, F.G.; Samudrala, D.; Cristescu, S.M.; Costa, G.; Harren, F.J.M.; Woltering, E.J. Chillinginduced changes in aroma volatile profiles in tomato. Food Bioprocess Technol. 2015, 8, 1442-1454. [CrossRef] [PubMed]

18. Tieman, D.; Zhu, G.; Resende, M.F.R.; Lin, T.; Nguyen, C.; Bies, D.; Rambla, J.L.; Beltran, K.S.O.; Taylor, M.; Zhang, B.; et al. A chemical genetic roadmap to improved tomato flavor. Science 2017, 355, 391-394. [CrossRef] [PubMed]

19. William, L.G.; Stanley, A.B. Genetics in Breeding of Processing Tomatoes. In Tomato Production, Processing and Technology; Elsevier: Amsterdam, The Netherlands, 1992; pp. 83-101.

20. Krumbein, A.; Peters, P.; Brückner, B. Flavour compounds and a quantitative descriptive analysis of tomatoes (Lycopersicon esculentum Mill.) of different cultivars in short-term storage. Postharvest Biol. Technol. 2004, 32, 15-28. [CrossRef]

21. Lahoz, I.; Pérez de Castro, A.; Valcárcel, M.; Macua, J.I.; Beltrán, J.; Roselló, S.; Cebolla-Cornejo, J. Effect of water deficit on the agronomical performance and quality of processing tomato. Sci. Hortic. 2016, 200, 55-65. [CrossRef]

22. Maul, F.; Sargent, S.A.; Sims, C.A.; Baldwin, E.A.; Balaban, M.O.; Huber, D.J. Tomato flavor and aroma quality as affected by storage temperature. J. Food Sci. 2000, 65, 1228-1237. [CrossRef]

23. Mauro, R.P.; Rizzo, V.; Leonardi, C.; Mazzaglia, A.; Muratore, G.; Distefano, M.; Sabatino, L.; Giuffrida, F. Influence of harvest stage and rootstock genotype on compositional and sensory profile of the elongated tomato cv. "Sir Elyan". Agriculture 2020, 10, 17. [CrossRef]

24. Powell, A.L.T.; Nguyen, C.V.; Hill, T.; Cheng, K.L.L.; Figueroa-Balderas, R.; Aktas, H.; Ashrafi, H.; Pons, C.; Fernández-Muñoz, R.; Vicente, A.; et al. Uniform ripening encodes a Golden 2-like transcription factor regulating tomato fruit chloroplast development. Science 2012, 336, 1711-1715. [CrossRef] [PubMed]

25. Kegge, W.; Pierik, R. Biogenic volatile organic compounds and plant competition. Trends Plant Sci. 2010, 15, 126-132. [CrossRef] [PubMed]

26. Wang, L.; Baldwin, E.A.; Bai, J. Recent advance in aromatic volatile research in tomato fruit: The metabolisms and regulations. Food Bioprocess Technol. 2016, 9, 203-216. [CrossRef]

27. Buttery, R.G.; Ling, L.C. Volatile Components of Tomato Fruit and Plant Parts. In Bioactive Volatile Compounds from Plants; Teranishi, R., Buttery, R.G., Sugisawa, H., Eds.; American Chemical Society: Washington, DC, USA, 1993; pp. 23-34.

28. Buttery, R.G.; Teranishi, R.; Ling, L.C. Fresh tomato aroma volatiles: A quantitative study. J. Agric. Food Chem. 1987, 35, 540-544. [CrossRef]

29. Guadagni, D.G.; Buttery, R.G.; Okano, S. Odour thresholds of some organic compounds associated with food flavours. J. Sci. Food Agric. 1963, 14, 761-765. [CrossRef]

30. Guadagni, D.G.; Buttery, R.G.; Harris, J. Odour intensities of hop oil components. J. Sci. Food Agric. 1966, 17, 142-144. [CrossRef]

31. Rambla, J.L.; Tikunov, Y.M.; Monforte, A.J.; Bovy, A.G.; Granell, A. The expanded tomato fruit volatile landscape. J. Exp. Bot. 2014, 65, 4613-4623. [CrossRef]

32. Bezman, Y.; Mayer, F.; Takeoka, G.R.; Buttery, R.G.; Ben-Oliel, G.; Rabinowitch, H.D.; Naim, M. Differential effects of tomato (Lycopersicon esculentum Mill) matrix on the volatility of important aroma compounds. J. Agric. Food Chem. 2003, 51, 722-726. [CrossRef]

33. Tandon, K.S.; Baldwin, E.A.; Scott, J.W.; Shewfelt, R.L. Linking sensory descriptors to volatile and nonvolatile components of fresh tomato flavor. J. Food Sci. 2003, 68, 2366-2371. [CrossRef] 
34. Vogel, J.T.; Walter, M.H.; Giavalisco, P.; Lytovchenko, A.; Kohlen, W.; Charnikhova, T.; Simkin, A.J.; Goulet, C.; Strack, D.; Bouwmeester, H.J.; et al. SICCD7 controls strigolactone biosynthesis, shoot branching and mycorrhiza-induced apocarotenoid formation in tomato. Plant J. 2010, 61, 300-311. [CrossRef] [PubMed]

35. Tieman, D.; Bliss, P.; McIntyre, L.M.; Blandon-Ubeda, A.; Bies, D.; Odabasi, A.Z.; Rodríguez, G.R.; van der Knaap, E.; Taylor, M.G.; Goulet, C.; et al. The chemical interactions underlying tomato flavor preferences. Curr. Biol. 2012, 22, 1035-1039. [CrossRef]

36. Causse, M.; Albert, E.; Sauvage, C. Developing Tomato Varieties with Improved Flavour. In Achieving Sustainable Cultivation of Tomatoes; Mattoo, A., Handa, A., Eds.; Burleigh Dodds Science Publishing: Cambridge, UK, 2017; pp. $283-313$.

37. Chen, G.; Hackett, R.; Walker, D.; Taylor, A.; Lin, Z.; Grierson, D. Identification of a specific isoform of tomato lipoxygenase (TomloxC) involved in the generation of fatty acid-derived flavor compounds. Plant Physiol. 2004, 136, 2641-2651. [CrossRef] [PubMed]

38. Davidovich-Rikanati, R.; Azulay, Y.; Sitrit, Y.; Tadmor, Y.; Lewinsohn, E. Tomato Aroma: Biochemistry and Biotechnology. In Biotechnology in Flavor Production; Havkin-Frenkel, D., Dudai, N., Eds.; Blackwell Publishing Ltd.: Hoboken, NJ, USA, 2009; pp. 118-129. ISBN 140515649X.

39. Martina, M.; Tikunov, Y.; Portis, E.; Bovy, A.G. The genetic basis of tomato aroma. Genes 2021, 12, 226. [CrossRef] [PubMed]

40. Shen, J.; Tieman, D.; Jones, J.B.; Taylor, M.G.; Schmelz, E.; Huffaker, A.; Bies, D.; Chen, K.; Klee, H.J. A 13-lipoxygenase, TomloxC, is essential for synthesis of C5 flavour volatiles in tomato. J. Exp. Bot. 2014, 65, 419-428. [CrossRef] [PubMed]

41. Tieman, D.M.; Loucas, H.M.; Kim, J.Y.; Clark, D.G.; Klee, H.J. Tomato phenylacetaldehyde reductases catalyze the last step in the synthesis of the aroma volatile 2-phenylethanol. Phytochemistry 2007, 68, 2660-2669. [CrossRef] [PubMed]

42. Gonda, I.; Bar, E.; Portnoy, V.; Lev, S.; Burger, J.; Schaffer, A.A.; Tadmor, Y.; Gepstein, S.; Giovannoni, J.J.; Katzir, N.; et al. Branched-chain and aromatic amino acid catabolism into aroma volatiles in Cucumis melo L. fruit. J. Exp. Bot. 2010, 61, 1111-1123. [CrossRef] [PubMed]

43. Maloney, G.S.; Kochevenko, A.; Tieman, D.M.; Tohge, T.; Krieger, U.; Zamir, D.; Taylor, M.G.; Fernie, A.R.; Klee, H.J. Characterization of the branched-chain amino acid aminotransferase enzyme family in tomato. Plant Physiol. 2010, 153, 925-936. [CrossRef] [PubMed]

44. Kochevenko, A.; Araújo, W.L.; Maloney, G.S.; Tieman, D.M.; Do, P.T.; Taylor, M.G.; Klee, H.J.; Fernie, A.R. Catabolism of branched chain amino acids supports respiration but not volatile synthesis in tomato fruits. Mol. Plant 2012, 5, 366-375. [CrossRef]

45. Buttery, R.G.; Teranishi, R.; Ling, L.C.; Flath, R.A.; Stern, D.J. Quantitative studies on origins of fresh tomato aroma volatiles. J. Agric. Food Chem. 1988, 36, 1247-1250. [CrossRef]

46. Vogel, J.T.; Tieman, D.M.; Sims, C.A.; Odabasi, A.Z.; Clark, D.G.; Klee, H.J. Carotenoid content impacts flavor acceptability in tomato (Solanum lycopersicum). J. Sci. Food Agric. 2010, 90, 2233-2240. [CrossRef] [PubMed]

47. Simkin, A.J. Carotenoids and apocarotenoids in planta: Their role in plant development, contribution to the flavour and aroma of fruits and flowers, and their nutraceutical benefits. Plants 2021, 10, 2321. [CrossRef] [PubMed]

48. Vogel, J.T.; Tan, B.C.; McCarty, D.R.; Klee, H.J. The carotenoid cleavage dioxygenase 1 enzyme has broad substrate specificity, cleaving multiple carotenoids at two different bond positions. J. Biol. Chem. 2008, 283, 11364-11373. [CrossRef] [PubMed]

49. Ilg, A.; Beyer, P.; Al-Babili, S. Characterization of the rice carotenoid cleavage dioxygenase 1 reveals a novel route for geranial biosynthesis. FEBS J. 2009, 276, 736-747. [CrossRef] [PubMed]

50. Tandon, K.S.; Baldwin, E.A.; Shewfelt, R.L. Aroma perception of individual volatile compounds in fresh tomatoes (Lycopersicon esculentum, Mill.) as affected by the medium of evaluation. Postharvest Biol. Technol. 2000, 20, 261-268. [CrossRef]

51. Rottet, S.; Devillers, J.; Glauser, G.; Douet, V.; Besagni, C.; Kessler, F. Identification of plastoglobules as a site of carotenoid cleavage. Front. Plant Sci. 2016, 7, 1855. [CrossRef] [PubMed]

52. Simkin, A.J.; Schwartz, S.H.; Auldridge, M.; Taylor, M.G.; Klee, H.J. The tomato carotenoid cleavage dioxygenase 1 genes contribute to the formation of the flavor volatiles $\beta$-ionone, pseudoionone, and geranylacetone. Plant J. 2004, 40, 882-892. [CrossRef]

53. Ilg, A.; Bruno, M.; Beyer, P.; Al-Babili, S. Tomato carotenoid cleavage dioxygenases 1A and 1B: Relaxed double bond specificity leads to a plenitude of dialdehydes, mono-apocarotenoids and isoprenoid volatiles. FEBS Open Bio 2014, 4, 584-593. [CrossRef]

54. Tieman, D.; Zeigler, M.; Schmelz, E.; Taylor, M.G.; Rushing, S.; Jones, J.B.; Klee, H.J. Functional analysis of a tomato salicylic acid methyl transferase and its role in synthesis of the flavor volatile methyl salicylate. Plant J. 2010, 62, 113-123. [CrossRef]

55. Nagegowda, D.A. Plant volatile terpenoid metabolism: Biosynthetic genes, transcriptional regulation and subcellular compartmentation. FEBS Lett. 2010, 584, 2965-2973. [CrossRef]

56. Waché, Y.; Bosser-DeRatuld, A.; Lhuguenot, J.C.; Belin, J.M. Effect of cis/trans isomerism of $\beta$-carotene on the ratios of volatile compounds produced during oxidative degradation. J. Agric. Food Chem. 2003, 51, 1984-1987. [CrossRef] [PubMed]

57. Mageroy, M.H.; Tieman, D.M.; Floystad, A.; Taylor, M.G.; Klee, H.J. A Solanum lycopersicum catechol-O-methyltransferase involved in synthesis of the flavor molecule guaiacol. Plant J. 2012, 69, 1043-1051. [CrossRef] [PubMed]

58. Koeduka, T.; Fridman, E.; Gang, D.R.; Vassão, D.G.; Jackson, B.L.; Kish, C.M.; Orlova, I.; Spassova, S.M.; Lewis, N.G.; Noel, J.P.; et al. Eugenol and isoeugenol, characteristic aromatic constituents of spices, are biosynthesized via reduction of a coniferyl alcohol ester. Proc. Natl. Acad. Sci. USA 2006, 103, 10128-10133. [CrossRef] [PubMed]

59. James, D.G.; Price, T.S. Field-testing of methyl salicylate for recruitment and retention of beneficial insects in grapes and hops. J. Chem. Ecol. 2004, 30, 1613-1628. [CrossRef] [PubMed] 
60. Krumbein, A.; Auerswald, H. Characterization of aroma volatiles in tomatoes by sensory analyses. Nahr. Food 1998, 42, 395-399. [CrossRef]

61. WIlliams, P.J. Hydrolytic Flavor Release in Fruit and Wines through Hydrolysis of Nonvolatile Precursors. In Flavor Science: Sensible Principles and Techniques; Acree, T.E., Teranishi, R., Eds.; American Chemical Society: Washington, DC, USA, 1993; pp. 287-308.

62. Roscher, R.; Bringmann, G.; Schreier, P.; Schwab, W. Radiotracer studies on the formation of 2,5-dimethyl-4-hydroxy-3(2H)furanone in detached ripening strawberry fruits. J. Agric. Food Chem. 1998, 46, 1488-1493. [CrossRef]

63. Buttery, R.G.; Teranishi, R.; Ling, L.C.; Turnbaugh, J.G. Quantitative and sensory studies on tomato paste volatiles. J. Agric. Food Chem. 1990, 38, 336-340. [CrossRef]

64. Williams, M.P.; Nelson, P.E. Prediction of dimethyl sulfide production in tomato serum. J. Food Sci. 1976, 41, 1241-1242. [CrossRef]

65. Rouphael, Y.; Cardarelli, M.; Bassal, A.; Leonardi, C.; Giuffrida, F.; Colla, G. Vegetable quality as affected by genetic, agronomic and environmental factors. J. Food Agric. Environ. 2012, 10, 680-688.

66. Bergougnoux, V. The history of tomato: From domestication to biopharming. Biotechnol. Adv. 2014, 32, 170-189. [CrossRef]

67. Picton, S.; Barton, S.L.; Bouzayen, M.; Hamilton, A.J.; Grierson, D. Altered fruit ripening and leaf senescence in tomatoes expressing an antisense ethylene-forming enzyme transgene. Plant J. 1993, 3, 469-481. [CrossRef]

68. McGlasson, W.B.; Last, J.H.; Shaw, K.J.; Meldrum, S.K. Influence of the non-ripening mutants rin and nor on the aroma of tomato fruit. HortScience 1987, 22, 632-634.

69. Alexander, L.; Grierson, D. Ethylene biosynthesis and action in tomato: A model for climacteric fruit ripening. J. Exp. Bot. 2002, 53, 2039-2055. [CrossRef] [PubMed]

70. Hamilton, A.J.; Lycett, G.W.; Grierson, D. Antisense gene that inhibits synthesis of the hormone ethylene in transgenic plants. Nature 1990, 346, 284-287. [CrossRef]

71. Causse, M. QTL analysis of fruit quality in fresh market tomato: A few chromosome regions control the variation of sensory and instrumental traits. J. Exp. Bot. 2002, 53, 2089-2098. [CrossRef] [PubMed]

72. Tadmor, Y.; Fridman, E.; Gur, A.; Larkov, O.; Lastochkin, E.; Ravid, U.; Zamir, D.; Lewinsohn, E. Identification of malodorous, a wild species allele affecting tomato aroma that was selected against during domestication. J. Agric. Food Chem. 2002, 50, 2005-2009. [CrossRef]

73. Saliba-Colombani, V.; Causse, M.; Langlois, D.; Philouze, J.; Buret, M. Genetic analysis of organoleptic quality in fresh market tomato. 1. Mapping QTLs for physical and chemical traits. Theor. Appl. Genet. 2001, 102, 259-272. [CrossRef]

74. Tieman, D.M.; Zeigler, M.; Schmelz, E.A.; Taylor, M.G.; Bliss, P.; Kirst, M.; Klee, H.J. Identification of loci affecting flavour volatile emissions in tomato fruits. J. Exp. Bot. 2006, 57, 887-896. [CrossRef]

75. Mathieu, S.; Cin, V.D.; Fei, Z.; Li, H.; Bliss, P.; Taylor, M.G.; Klee, H.J.; Tieman, D.M. Flavour compounds in tomato fruits: Identification of loci and potential pathways affecting volatile composition. J. Exp. Bot. 2009, 60, 325-337. [CrossRef]

76. Garbowicz, K.; Liu, Z.; Alseekh, S.; Tieman, D.; Taylor, M.; Kuhalskaya, A.; Ofner, I.; Zamir, D.; Klee, H.J.; Fernie, A.R.; et al. Quantitative trait loci analysis identifies a prominent gene involved in the production of fatty acid-derived flavor volatiles in tomato. Mol. Plant 2018, 11, 1147-1165. [CrossRef]

77. Allevato, E.; Mauro, R.P.; Stazi, S.R.; Marabottini, R.; Leonardi, C.; Ierna, A.; Giuffrida, F. Arsenic accumulation in grafted melon plants: Role of rootstock in modulating root-to-shoot translocation and physiological response. Agronomy 2019, 9, 828. [CrossRef]

78. Mauro, R.P.; Agnello, M.; Distefano, M.; Sabatino, L.; San Bautista Primo, A.; Leonardi, C.; Giuffrida, F. Chlorophyll fluorescence, photosynthesis and growth of tomato plants as affected by long-term oxygen root zone deprivation and grafting. Agronomy 2020, 10, 137. [CrossRef]

79. Mauro, R.P.; Agnello, M.; Onofri, A.; Leonardi, C.; Giuffrida, F. Scion and rootstock differently influence growth, yield and quality characteristics of cherry tomato. Plants 2020, 9, 1725. [CrossRef] [PubMed]

80. Bartoshuk, L.M.; Klee, H.J. Better fruits and vegetables through sensory analysis. Curr. Biol. 2013, 23, R374-R378. [CrossRef] [PubMed]

81. Krumbein, A.; Schwarz, D. Grafting: A possibility to enhance health-promoting and flavour compounds in tomato fruits of shaded plants? Sci. Hortic. 2013, 149, 97-107. [CrossRef]

82. Lewinsohn, E.; Sitrit, Y.; Bar, E.; Azulay, Y.; Meir, A.; Zamir, D.; Tadmor, Y. Carotenoid pigmentation affects the volatile composition of tomato and watermelon fruits, as revealed by comparative genetic analyses. J. Agric. Food Chem. 2005, 53, 3142-3148. [CrossRef] [PubMed]

83. Casals, J.; Rivera, A.; Sabaté, J.; del Castillo, R.R.; Simó, J. Cherry and fresh market tomatoes: Differences in chemical, morphological, and sensory traits and their implications for consumer acceptance. Agronomy 2019, 9, 9. [CrossRef]

84. Lee, J.H.J.; Jayaprakasha, G.K.; Avila, C.A.; Crosby, K.M.; Patil, B.S. Metabolomic studies of volatiles from tomatoes grown in net-house and open-field conditions. Food Chem. 2019, 275, 282-291. [CrossRef]

85. Slimestad, R.; Verheul, M.J. Seasonal Variations in the Level of Plant Constituents in Greenhouse Production of Cherry Tomatoes. J. Agric. Food Chem. 2005, 53, 3114-3119. [CrossRef]

86. Cebolla-Cornejo, J.; Roselló, S.; Valcárcel, M.; Serrano, E.; Beltrán, J.; Nuez, F. Evaluation of genotype and environment effects on taste and aroma flavor components of Spanish fresh tomato varieties. J. Agric. Food Chem. 2011, 59, 2440-2450. [CrossRef]

87. Wang, Y.T.; Huang, S.W.; Liu, R.L.; Jin, J.Y. Effects of nitrogen application on flavor compounds of cherry tomato fruits. J. Plant Nutr. Soil Sci. 2007, 170, 461-468. [CrossRef] 
88. Wang, Y.T.; Liu, R.L.; Huang, S.W.; Jin, J.Y. Effects of potassium application on flavor compounds of cherry tomato fruits. J. Plant Nutr. 2009, 32, 1451-1468. [CrossRef]

89. Veit-Köhler, U.; Krumbein, A.; Kosegarten, H. Effect of different water supply on plant growth and fruit quality of Lycopersicon esculentum. J. Plant Nutr. Soil Sci. 1999, 162, 583-588. [CrossRef]

90. Hart, M.; Ehret, D.L.; Krumbein, A.; Leung, C.; Murch, S.; Turi, C.; Franken, P. Inoculation with arbuscular mycorrhizal fungi improves the nutritional value of tomatoes. Mycorrhiza 2015, 25, 359-376. [CrossRef] [PubMed]

91. Baldwin, E.A.; Nisperos-Carriedo, M.O.; Moshonas, M.G. Quantitative analysis of flavor and other volatiles and for certain constituents of two tomato cultivars during ripening. J. Am. Soc. Hortic. Sci. 1991, 116, 265-269. [CrossRef]

92. Tinyane, P.P.; Sivakumar, D.; Soundy, P. Influence of photo-selective netting on fruit quality parameters and bioactive compounds in selected tomato cultivars. Sci. Hortic. 2013, 161, 340-349. [CrossRef]

93. Pasković, I.; Soldo, B.; Goreta Ban, S.; Radić, T.; Lukić, M.; Urlić, B.; Mimica, M.; Brkić Bubola, K.; Colla, G.; Rouphael, Y.; et al. Fruit quality and volatile compound composition of processing tomato as affected by fertilisation practices and arbuscular mycorrhizal fungi application. Food Chem. 2021, 359, 129961. [CrossRef]

94. Liu, T.; Zhu, W.; Huang, J.; Chen, H.; Nie, R.; Li, C.M. Comparison of the nutritional as well as the volatile composition of in-season and off-season Hezuo 903 tomato at red stage. Eur. Food Res. Technol. 2017, 243, 203-214. [CrossRef]

95. Dorais, M.; Dorval, R.; Demers, D.A.; Micevic, D.; Turcotte, G.; Papadopoulos, P.; Ehret, D.L.; Gosselin, A. Improving tomato fruit quality by increasing salinity: Effects on ion uptake, growth and yield. Acta Hortic. 1998, 511, 185-195. [CrossRef]

96. Ruiz-Cisneros, M.F.; de Jesús Ornelas-Paz, J.; Olivas-Orozco, G.I.; Acosta-Muñiz, C.H.; Salas-Marina, M.Á.; Molina-Corral, F.J.; Berlanga-Reyes, D.I.; Fernández-Pavía, S.P.; Cambero-Campos, O.J.; Rios-Velasco, C. Effect of rhizosphere inoculation with Bacillus strains and phytopathogens on the contents of volatiles and human health-related compounds in tomato fruits. Food Sci. Technol. 2021, 2061, 1-12. [CrossRef]

97. Baldwin, E.A.; Scott, J.W.; Bai, J. Sensory and chemical flavor analyses of tomato genotypes grown in Florida during three different growing seasons in multiple years. J. Am. Soc. Hortic. Sci. 2015, 140, 490-503. [CrossRef]

98. Thybo, A.K.; Edelenbos, M.; Christensen, L.P.; Sørensen, J.N.; Thorup-Kristensen, K. Effect of organic growing systems on sensory quality and chemical composition of tomatoes. LWT-Food Sci. Technol. 2006, 39, 835-843. [CrossRef]

99. Wright, D.H.; Harris, N.D. Effect of Nitrogen and Potassium Fertilization on Tomato Flavor. J. Agric. Food Chem. 1985, 33, 355-358. [CrossRef]

100. Klein, D.; Gkisakis, V.; Krumbein, A.; Livieratos, I.; Köpke, U. Old and endangered tomato cultivars under organic greenhouse production: Effect of harvest time on flavour profile and consumer acceptance. Int. J. Food Sci. Technol. 2010, 45, 2250-2257. [CrossRef]

101. Dalal, K.B.; Olson, L.E.; Yu, M.H.; Salunkhe, D.K. Gas chromatography of the field-, glass-Greenhouse-grown, and artificially ripened tomatoes. Lycopersicon esculentum mill. Phytochemistry 1967, 6, 155-157. [CrossRef]

102. Du, X.; Song, M.; Baldwin, E.; Rouseff, R. Identification of sulphur volatiles and GC-olfactometry aroma profiling in two fresh tomato cultivars. Food Chem. 2015, 171, 306-314. [CrossRef] [PubMed]

103. Jin, C.; Du, S.; Wang, Y.; Condon, J.; Lin, X.; Zhang, Y. Carbon dioxide enrichment by composting in greenhouses and its effect on vegetable production. J. Plant Nutr. Soil Sci. 2009, 172, 418-424. [CrossRef]

104. Kläring, H.P.; Hauschild, C.; Heißner, A.; Bar-Yosef, B. Model-based control of $\mathrm{CO}_{2}$ concentration in greenhouses at ambient levels increases cucumber yield. Agric. For. Meteorol. 2007, 143, 208-216. [CrossRef]

105. Rangaswamy, T.C.; Sridhara, S.; Ramesh, N.; Gopakkali, P.; El-Ansary, D.O.; Mahmoud, E.A.; Abdelmohsen, S.A.M.; Abdelbacki, A.M.M.; Elansary, H.O.; Abdel-Hamid, A.M.E. Assessing the impact of higher levels of $\mathrm{CO}_{2}$ and temperature and their interactions on tomato (Solanum lycopersicum L.). Plants 2021, 10, 256. [CrossRef]

106. Li, Y.; Ding, Y.; Li, D.; Miao, Z. Automatic carbon dioxide enrichment strategies in the greenhouse: A review. Biosyst. Eng. 2018, 171, 101-119. [CrossRef]

107. Liu, J.; Peng, X.; Abdelhakim, L.O.A.; Fang, L.; Wei, Z.; Liu, F. Carbon dioxide elevation combined with sufficient irrigation and nitrogen fertilization improves fruit quality of tomato grown in glasshouse. Arch. Agron. Soil Sci. 2020, 67, 1134-1149. [CrossRef]

108. Zhang, Z.; Liu, L.; Zhang, M.; Zhang, Y.; Wang, Q. Effect of carbon dioxide enrichment on health-promoting compounds and organoleptic properties of tomato fruits grown in greenhouse. Food Chem. 2014, 153, 157-163. [CrossRef] [PubMed]

109. Loughrin, J.H.; Kasperbauer, M.J. Aroma of fresh strawberries is enhanced by ripening over red versus black mulch. J. Agric. Food Chem. 2002, 50, 161-165. [CrossRef]

110. Sivakumar, D.; Jifon, J.; Soundy, P. Spectral quality of photo-selective shade nettings improves antioxidants and overall quality in selected fresh produce after postharvest storage. Food Rev. Int. 2018, 34, 290-307. [CrossRef]

111. Jiménez, E.; Lanza, B.; Antiñolo, M.; Albaladejo, J. Photooxidation of leaf-wound oxygenated compounds, 1-penten-3-ol, (z)-3-hexen-1-ol, and 1-penten-3-one, initiated by OH radicals and sunlight. Environ. Sci. Technol. 2009, 43, 1831-1837. [CrossRef]

112. Sun, H.; Ni, H.; Yang, Y.; Wu, L.; Cai, H.N.; Xiao, A.F.; Chen, F. Investigation of sunlight-induced deterioration of aroma of pummelo (Citrus maxima) essential oil. J. Agric. Food Chem. 2014, 62, 11818-11830. [CrossRef]

113. Thybo, A.K.; Bechmann, I.E.; Brandt, K. Integration of sensory and objective measurements of tomato quality: Quantitative assessment of the effect of harvest date as compared with growth medium (soil versus rockwool), electrical conductivity, variety and maturity. J. Sci. Food Agric. 2005, 85, 2289-2296. [CrossRef] 
114. El Hadi, M.A.M.; Zhang, F.J.; Wu, F.F.; Zhou, C.H.; Tao, J. Advances in fruit aroma volatile research. Molecules 2013, 18, 8200-8229. [CrossRef]

115. Patanè, C.; Tringali, S.; Sortino, O. Effects of deficit irrigation on biomass, yield, water productivity and fruit quality of processing tomato under semi-arid Mediterranean climate conditions. Sci. Hortic. 2011, 129, 590-596. [CrossRef]

116. Zegbe-Domínguez, J.A.; Behboudian, M.H.; Lang, A.; Clothier, B.E. Deficit irrigation and partial rootzone drying maintain fruit dry mass and enhance fruit quality in "Petopride" processing tomato (Lycopersicon esculentum, Mill.). Sci. Hortic. 2003, 98, 505-510. [CrossRef]

117. Li, J.; Gao, Y.; Zhang, X.; Tian, P.; Li, J.; Tian, Y. Comprehensive comparison of different saline water irrigation strategies for tomato production: Soil properties, plant growth, fruit yield and fruit quality. Agric. Water Manag. 2019, 213, 521-533. [CrossRef]

118. Tomescu, D.; Şumǎlan, R.; Copolovici, L.; Copolovici, D. The influence of soil salinity on volatile organic compounds emission and photosynthetic parameters of Solanum lycopersicum L. varieties. Open Life Sci. 2017, 12, 135-142. [CrossRef]

119. Cliff, M.A.; Li, J.B.; Toivonen, P.M.A.; Ehret, D.L. Effects of nutrient solution electrical conductivity on the compositional and sensory characteristics of greenhouse tomato fruit. Postharvest Biol. Technol. 2012, 74, 132-140. [CrossRef]

120. Lykogianni, M.; Bempelou, E.; Karamaouna, F.; Aliferis, K.A. Do pesticides promote or hinder sustainability in agriculture? The challenge of sustainable use of pesticides in modern agriculture. Sci. Total Environ. 2021, 795, 148625. [CrossRef]

121. Mauro, R.P.; Sortino, O.; Dipasquale, M.; Mauromicale, G. Phenological and growth response of legume cover crops to shading. J. Agric. Sci. 2014, 152, 917-931. [CrossRef]

122. Castello, I.; D'Emilio, A.; Raviv, M.; Vitale, A. Soil solarization as a sustainable solution to control tomato Pseudomonads infections in greenhouses. Agron. Sustain. Dev. 2017, 37, 59. [CrossRef]

123. Begum, N.; Qin, C.; Ahanger, M.A.; Raza, S.; Khan, M.I.; Ashraf, M.; Ahmed, N.; Zhang, L. Role of Arbuscular Mycorrhizal Fungi in Plant Growth Regulation: Implications in Abiotic Stress Tolerance. Front. Plant Sci. 2019, 10, 1068. [CrossRef]

124. Bona, E.; Cantamessa, S.; Massa, N.; Manassero, P.; Marsano, F.; Copetta, A.; Lingua, G.; D'Agostino, G.; Gamalero, E.; Berta, G. Arbuscular mycorrhizal fungi and plant growth-promoting pseudomonads improve yield, quality and nutritional value of tomato: A field study. Mycorrhiza 2017, 27, 1-11. [CrossRef]

125. Compant, S.; Samad, A.; Faist, H.; Sessitsch, A. A review on the plant microbiome: Ecology, functions, and emerging trends in microbial application. J. Adv. Res. 2019, 19, 29-37. [CrossRef]

126. Yousef, A.F.; Youssef, M.A.; Ali, M.M.; Ibrahim, M.M.; Xu, Y.; Mauro, R.P. Improved growth and yield response of Jew's mallow (Corchorus olitorius L.) plants through biofertilization under semi-arid climate conditions in Egypt. Agronomy 2020, 10, 14. [CrossRef]

127. Hammerbacher, A.; Coutinho, T.A.; Gershenzon, J. Roles of plant volatiles in defence against microbial pathogens and microbial exploitation of volatiles. Plant Cell Environ. 2019, 42, 2827-2843. [CrossRef] [PubMed]

128. Tohge, T.; Alseekh, S.; Fernie, A.R. On the regulation and function of secondary metabolism during fruit development and ripening. J. Exp. Bot. 2014, 65, 4599-4611. [CrossRef] [PubMed]

129. Brezmes, J.; Luisa, M.; Fructuoso, L.; Llobet, E.; Vilanova, X.; Recasens, I.; Orts, J.; Saiz, G.; Correig, X. Evaluation of an electronic nose to assess fruit ripeness. IEEE Sens. J. 2005, 5, 97-108. [CrossRef]

130. Galliard, T.; Matthew, J.A.; Wright, A.J.; Fishwick, M.J. The enzymic breakdown of lipids to volatile and non-volatile carbonyl fragments in disrupted tomato fruits. J. Sci. Food Agric. 1977, 28, 863-868. [CrossRef]

131. Kader, A.A. Effects of postharvest handling procedures on tomato quality. Acta Hortic. 1986, 190, 209-221. [CrossRef]

132. Saltveit, M.E. Fruit ripening and fruit quality. In Tomatoes; CABI Publishing: Wallingford, UK, 2005; pp. 145-170. ISBN 0851993966.

133. Zhang, Z.M.; Zeng, D.D.; Li, G.K. Study of the volatile composition of tomato during storage by a combination sampling method coupled with gas chromatography/mass spectrometry. J. Sci. Food Agric. 2008, 88, 116-124. [CrossRef]

134. Distefano, M.; Arena, E.; Mauro, R.P.; Brighina, S.; Leonardi, C.; Fallico, B.; Giuffrida, F. Effects of Genotype, Storage Temperature and Time on Quality and Compositional Traits of Cherry Tomato. Foods 2020, 9, 1729. [CrossRef]

135. Ponce-Valadez, M.; Escalona-Buendía, H.B.; Villa-Hernández, J.M.; de León-Sánchez, F.D.; Rivera-Cabrera, F.; Alia-Tejacal, I.; Pérez-Flores, L.J. Effect of refrigerated storage $\left(12.5^{\circ} \mathrm{C}\right)$ on tomato (Solanum lycopersicum) fruit flavor: A biochemical and sensory analysis. Postharvest Biol. Technol. 2016, 111, 6-14. [CrossRef]

136. Wu, Q.; Tao, X.; Ai, X.; Luo, Z.; Mao, L.; Ying, T.; Li, L. Contribution of abscisic acid to aromatic volatiles in cherry tomato (Solanum lycopersicum L.) fruit during postharvest ripening. Plant Physiol. Biochem. 2018, 130, 205-214. [CrossRef]

137. Wu, Q.; Tao, X.; Ai, X.; Luo, Z.; Mao, L.; Ying, T.; Li, L. Effect of exogenous auxin on aroma volatiles of cherry tomato (Solanum lycopersicum L.) fruit during postharvest ripening. Postharvest Biol. Technol. 2018, 146, 108-116. [CrossRef]

138. Kelebek, H.; Kesen, S.; Sonmezdag, A.S.; Cetiner, B.; Kola, O.; Selli, S. Characterization of the key aroma compounds in tomato pastes as affected by hot and cold break process. J. Food Meas. Charact. 2018, 12, 2461-2474. [CrossRef]

139. Viljanen, K.; Lille, M.; Heiniö, R.L.; Buchert, J. Effect of high-pressure processing on volatile composition and odour of cherry tomato purée. Food Chem. 2011, 129, 1759-1765. [CrossRef]

140. Colquhoun, T.A.; Schwieterman, M.L.; Gilbert, J.L.; Jaworski, E.A.; Langer, K.M.; Jones, C.R.; Rushing, G.V.; Hunter, T.M.; Olmstead, J.; Clark, D.G.; et al. Light modulation of volatile organic compounds from petunia flowers and select fruits. Postharvest Biol. Technol. 2013, 86, 37-44. [CrossRef]

141. Raffo, A.; Baiamonte, I.; Nardo, N.; Nicoli, S.; Moneta, E.; Peparaio, M.; Sinesio, F.; Paoletti, F. Impact of early harvesting and two cold storage technologies on eating quality of red ripe tomatoes. Eur. Food Res. Technol. 2018, 244, 805-818. [CrossRef] 
142. Wang, L.; Baldwin, E.A.; Plotto, A.; Luo, W.; Raithore, S.; Yu, Z.; Bai, J. Effect of methyl salicylate and methyl jasmonate pre-treatment on the volatile profile in tomato fruit subjected to chilling temperature. Postharvest Biol. Technol. 2015, 108, 28-38. [CrossRef]

143. Boukobza, F.; Taylor, A.J. Effect of postharvest treatment on flavour volatiles of tomatoes. Postharvest Biol. Technol. 2002, 25, 321-331. [CrossRef]

144. McDonald, R.E.; McCollum, T.G.; Baldwin, E.A. Prestorage heat treatments influence free sterols and flavor volatiles of tomatoes stored at chilling temperature. J. Am. Soc. Hortic. Sci. 1996, 121, 531-536. [CrossRef]

145. Deltsidis, A.I.; Pliakoni, E.D.; Baldwin, E.A.; Bai, J.; Plotto, A.; Brecht, J.K. Tomato flavor changes at chilling and non-chilling temperatures as influenced by controlled atmospheres. Acta Hortic. 2015, 1071, 703-710. [CrossRef]

146. Arah, I.; Arah, I.K.; Amaglo, H.; Kumah, E.K.; Ofori, H. Preharvest and Postharvest Factors Affecting the Quality and Shelf Life of Harvested Tomatoes: A Mini Review. Int. J. Agron. 2015, 2015, 478041. [CrossRef]

147. Salveit, M.E. Physical and Physiological Changes in Minimally Processed Fruits and Vegetable. In Phytochemistry of Fruit and Vegetables; Tomás-Barberán, A., Ed.; Oxford University Press: New York, NY, USA, 1997; pp. 205-220.

148. Beckles, D.M. Factors affecting the postharvest soluble solids and sugar content of tomato (Solanum lycopersicum L.) fruit. Postharvest Biol. Technol. 2012, 63, 129-140. [CrossRef]

149. Zou, J.; Chen, J.; Tang, N.; Gao, Y.; Hong, M.; Wei, W.; Cao, H.; Jian, W.; Li, N.; Deng, W.; et al. Transcriptome analysis of aroma volatile metabolism change in tomato (Solanum lycopersicum) fruit under different storage temperatures and 1-MCP treatment. Postharvest Biol. Technol. 2018, 135, 57-67. [CrossRef]

150. Saltveit, M.E. The rate of ion leakage from chilling-sensitive tissue does not immediately increase upon exposure to chilling temperatures. Postharvest Biol. Technol. 2002, 26, 295-304. [CrossRef]

151. Folta, K.M.; Childers, K.S. Light as a growth regulator: Controlling plant biology with narrow-bandwidth solid-state lighting systems. HortScience 2008, 43, 1957-1964. [CrossRef]

152. Gil, M.I.; Conesa, M.A.; Artés, F. Quality changes in fresh cut tomato as affected by modified atmosphere packaging. Postharvest Biol. Technol. 2002, 25, 199-207. [CrossRef]

153. Caleb, O.J.; Mahajan, P.V.; Al-Said, F.A.J.; Opara, U.L. Modified atmosphere packaging technology of fresh and fresh-cut produce and the microbial consequences-A review. Food Bioprocess Technol. 2013, 6, 303-329. [CrossRef]

154. Stern, D.J.; Buttery, R.G.; Teranishi, R.; Ling, L.; Scott, K.; Cantwell, M. Effect of storage and ripening on fresh tomato quality, Part I. Food Chem. 1994, 49, 225-231. [CrossRef]

155. Auerswald, H.; Peters, P.; Brückner, B.; Krumbein, A.; Kuchenbuch, R. Sensory analysis and instrumental measurements of short-term stored tomatoes (Lycopersicon esculentum Mill.). Postharvest Biol. Technol. 1999, 15, 323-334. [CrossRef]

156. Ratanachinakorn, B.; Klieber, A.; Simons, D.H. Effect of short-term controlled atmospheres and maturity on ripening and eating quality of tomatoes. Postharvest Biol. Technol. 1997, 11, 149-154. [CrossRef]

157. Bailén, G.; Guillén, F.; Castillo, S.; Serrano, M.; Valero, D.; Martínez-Romero, D. Use of Activated Carbon inside Modified Atmosphere Packages To Maintain Tomato Fruit Quality during Cold Storage. Food Chem. 2006, 54, 2229-2235. [CrossRef]

158. Wills, R.B.H.; Ku, V.V.V. Use of 1-MCP to extend the time to ripen of green tomatoes and postharvest life of ripe tomatoes. Postharvest Biol. Technol. 2002, 26, 85-90. [CrossRef]

159. Mir, N.; Canoles, M.; Beaudry, R.; Baldwin, E.; Mehla, C.P. Inhibiting tomato ripening with 1-Methylcyclopropene. J. Am. Soc. Hortic. Sci. 2004, 129, 112-120. [CrossRef]

160. Reymond, P.; Farmer, E.E. Jasmonate and salicylate as global signals for defense gene expression. Curr. Opin. Plant Biol. 1998, 1 , 404-411. [CrossRef]

161. Gould, W.A. Tomato Production, Processing and Technology, 3rd ed.; CTI Publications Inc.: Baltimore, MD, USA, 1992; ISBN $9781845696146184569614 X$.

162. Birtić, S.; Ginies, C.; Causse, M.; Renard, C.M.G.C.; Page, D. Changes in volatiles and glycosides during fruit maturation of two contrasted tomato (Solanum lycopersicum) lines. J. Agric. Food Chem. 2009, 57, 591-598. [CrossRef] [PubMed]

163. Guadagni, D.G.; Miers, J.C.; Venstrom, D.W. Concentration effect on odor addition or synergism in mixtures of methyl sulfide and tomato juice. J. Food Sci. 1969, 34, 630-632. [CrossRef]

164. Jeyaprakash, S.; Heffernan, J.E.; Driscoll, R.H.; Frank, D.C. Impact of drying technologies on tomato flavor composition and sensory quality. LWT 2020, 120, 108888. [CrossRef]

165. Rambla, J.L.; Alfaro, C.; Medina, A.; Zarzo, M.; Primo, J.; Granell, A. Tomato fruit volatile profiles are highly dependent on sample processing and capturing methods. Metabolomics 2015, 11, 1708-1720. [CrossRef]

166. Baenas, N.; Bravo, S.; García-Alonso, F.J.; Gil, J.V.; Periago, M.J. Changes in volatile compounds, flavour-related enzymes and lycopene in a refrigerated tomato juice during processing and storage. Eur. Food Res. Technol. 2021, 247, 975-984. [CrossRef]

167. Rodrigo, D.; Jolie, R.; Van Loey, A.; Hendrickx, M. Thermal and high pressure stability of tomato lipoxygenase and hydroperoxide lyase. J. Food Eng. 2007, 79, 423-429. [CrossRef]

168. Aguiló-Aguayo, I.; Soliva-Fortuny, R.; Martín-Belloso, O. Effects of high-intensity pulsed electric fields on lipoxygenase and hydroperoxide lyase activities in tomato juice. J. Food Sci. 2009, 74, C595-C601. [CrossRef] 